\title{
Immune Challenge and Immobilization Stress Induce Transcription of the Gene Encoding the CRF Receptor in Selective Nuclei of the Rat Hypothalamus
}

\author{
Serge Rivest, Nathalie Laflamme, and Rossella E. Nappi \\ Laboratory of Molecular Endocrinology, CHUL Research Center and Laval University, Québec, Canada G1V 4G2
}

The present study investigated the effect of intraperitoneal (i.p.) administration of endotoxin lipopolysaccharide (LPS) and immobilization stress on the genetic expression of corticotropin-releasing factor receptor (CRF-R) in the brains of conscious male Sprague-Dawley rats. One group of rats was killed at $1,3,6,9$, and $12 \mathrm{hr}$ after a single intraperitoneal injection of either the LPS $(250 \mu \mathrm{g} / 100 \mathrm{gm}$ of body weight) or the vehicle solution; the other group was killed before, immediately after, 1.5, 3, 6, and $12 \mathrm{hr}$ after a $90 \mathrm{~min}$ acute session of immobilization stress. Rats were deeply anesthetized and rapidly perfused with a solution of $4 \%$ paraformaldehyde-borax. Frozen brains were mounted on a microtome and cut from the olfactory bulb to the medulla in $30 \mu \mathrm{m}$ coronal sections. mRNA encoding the rat CRF-R was assayed by in situ hybridization histochemistry using a ${ }^{35}$ S-labeled riboprobe, and CRF-R localization within CRFimmunoreactive neurons in the PVN was determined using a combination of immunocytochemistry and in situ hybridization techniques. Strong basal levels of CRF-R transcripts were observed in several regions of the brain (piriform cortex, medial and basolateral nuclei of the amygdala, red nucleus, pontine gray, cerebellum, laterodorsal tegmental nucleus, caudal division of the zona incerta, nucleus incertus, spinal and principal sensory nuclei of the trigeminal nerve, and various layers of the cortex). A low to moderate signal was also detected in multiple sites (medial septal nucleus, nucleus of the diagonal band, supraoptic nucleus, arcuate nucleus of the hypothalamus, interpeduncular nucleus, and nucleus prepositus). Whereas vehicle-treated and control rats displayed hardly detectable signals of CRF-R mRNA in the paraventricular nucleus (PVN), CRF-R gene transcription was highly stimulated by LPS administration and immobilization stress in this hypothalamic structure. Indeed, the CRF-R mRNA signal was positive in the dorsomedial parvocellular PVN $3 \mathrm{hr}$ after LPS injection, strong and maximum in both

\footnotetext{
Received Aug. 12, 1994; revised Oct. 20, 1994; accepted Oct. 26, 1994.

This research was supported by the Fonds de la Recherche en Santé du Québec (FRSQ) and the Medical Research Council (MRC) of Canada. Serge Rivest is a Medical Research Council Scholar. Rossella E. Nappi is supported by the IRCCS S. Matteo, University of Pavia, Italy. We thank Dr. Wylie W. Vale, PBL, The Salk Institute, La Jolla, CA, for the generous gift of rat CRF-R cDNA and the rabbit anti-human/rat CRF serum, and Dr. Guy Drolet (CHUL Research Center, Québec, Canada) and Dr. Paul E. Sawchenko (The Salk Institute, La Jolla, CA) for invaluable advice and discussion.

Correspondence should be addressed to Dr. Serge Rivest, Laboratory of Molecular Endocrinology, CHUL Research Center and Laval University, 2705, boulevard Laurier, Québec, Canada GlV 4G2.

Copyright 1995 Society for Neuroscience 0270-6474/95/152680-16\$05.00/0
}

parvo- and magno-PVN at $6 \mathrm{hr}$ postinjection, and declined 9 and $12 \mathrm{hr}$ after treatment. Similarly, $90 \mathrm{~min}$ and $3 \mathrm{hr}$ after the immobilization session, mRNA encoding the CRF-R was highly expressed in the parvo-PVN and totally vanished $12 \mathrm{hr}$ after the stress. A lower but significant increase in the CRF-R transcript signal was also observed in the supraoptic nucleus $6 \mathrm{hr}$ after the LPS treatment. Systemic endotoxin and immobilization stress did not modulate the expression of CRF-R gene in other regions, which suggests that these types of challenges can induce a highly selective activation of CRF-R within hypothalamic nuclei directly involved in the regulation of neuroendocrine functions. CRF-immunoreactive neurons of the parvo-PVN expressed the CRF-R transcript after both the stress and the systemic LPS administration. Thus, CRF may play a role as neuromodulator, controlling directly the activity of neuroendocrine CRF motoneurons during immune challenge and other stressful circumstances for the organism.

[Key words: corticotropin-releasing factor, hypothalamic-pituitary-adrenal axis, in situ hybridization histochemistry, immunocytochemistry, immune response, male rats, neuroendocrinology, paraventricular nucleus of the hypothalamus, supraoptic nucleus of the hypothalamus]

Stress is associated with activation of the hypothalamic-pituitary-adrenal (HPA) axis, and this activation has indeed been proposed as a defining feature of the stress response. The primary mediator of this response is corticotropin-releasing factor (CRF), a 41-residue peptide acknowledged as the principal hypophysiotropic factor driving stress-induced adrenocorticotropic hormone (ACTH) secretion (Vale et al., 1981; Rivier and Plotsky, 1986). Although CRF is widely distributed within the CNS, the paraventricular nucleus (PVN) of the hypothalamus is the principal site of the parvocellular ncurosecretory ncurons responsible for delivering CRF to the hypophyseal portal system, an event that initiates the activity of the pituitary-adrenal axis (for review, see Sawchenko and Swanson, 1990). Indeed, destruction of this hypothalamic nucleus abolishes the increase in plasma ACTH and corticosterone levels caused by various acute challenges (Bruhn et al., 1984; Makara et al., 1986; Rivest and Richard, 1990; Rivest and Rivier, 1991). Moreover, stressors such as single and repeated exercise sessions (Rivest et al., 1992), foot-shock stress (Imaki et al., 1991; Rivest and Rivier, 1994), immobilization (Imaki et al., 1992a), systemic administration of the bacterial lipopolysaccharide (LPS) (Laflamme and Rivest, 1994), and treatment with interleukin-1 $\beta$ (Gong et al., 1991; Rivest et al., 1992; Brady et al., 1994; Ericsson et al., 
1994; Rivest and Rivier; 1994) all stimulate the immediate early gene (IEG) c-fos and CRF gene expression in the parvocellular division of the rat PVN. These independent indices of neuronal activation provide evidence that neuroendocrine CRF motoneurons are highly stimulated during various stressful conditions, and this phenomenon appears crucial to the appropriate control of ACTH release from the adenohypophysis.

Stress-induced alteration of CRF neuronal activity is not, however, limited to the PVN; exposure to foot shocks, for example, causes a rapid upregulation of CRF $\mathrm{mRNA}$ in Barrington's nucleus, a pontine cell group involved in the autonomic control of micturition (Imaki et al., 1991; Sawchenko et al., 1993). Imaki et al. (1991) have also reported that foot shock can produce a downregulation of CRF gene expression in the olfactory bulb, a structure known as the main relay for a sensory modality governing most rodent behavior (Sawchenko et al., 1993). Interestingly, although levels of CRF transcripts in the PVN are negatively regulated by glucocorticoids, Makino et al. (1994) found that chronic treatment with corticosterone increases CRF mRNA expression in the central nucleus of the amygdala. Within the PVN itself, CRFergic systems seem to respond differently to glucocorticoids because in adrenalectomized rats treated with corticosterone, CRF mRNA increased in the autonomic component of this hypothalamic nucleus (dorsal cap) and decreased in the medial parvocellular neurons (Swanson and Simmons, 1989). Glucocorticoids may therefore restrain their inhibitory influence on neuroendocrine CRF motoneurons during stress. Salt-loading challenge, on the other hand, causes a decrease in CRF transcripts in Barrington's nucleus and a marked increase in the magnocellular neurosecretory cells, an effect accompanied by a paradoxical reduction in CRF mRNA levels in the parvocellular PVN (Young, 1986; Imaki et al., 1992b; Sawchenko et al., 1993). Exercise training on a treadmill can also modulate CRF gene expression in sites other than the parvocellular PVN, such as the medial part of the medial geniculate complex and the lateral subdivision of the medial mammillary nucleus (Rivest et al., 1992). Relative levels of CRF mRNA in the parvocellular PVN are also significantly increased following an acute immune challenge with systemic LPS injection, but endotoxin did not alter the genetic expression of this stress-related neuropeptide in other brain regions (Laflamme and Rivest, 1994). Although the stimulation of CRF neurons in various regions of the brain depends on the type and intensity of the stress, little is known about the sites of action of the peptide in the brain of stressed animals.

In addition to being a potential modulator of the stress responses in various regions of the brain, CRF can also positively modulate its own expression. Indeed, we recently reported that central administration of the neuropeptide causes a rapid induction of $\mathrm{c}-$ fos and NGFI-B in CRF-immunoreactive (ir) neurons of the rat PVN (Parkes et al,, 1993). This IEG induction was also followed by an increase in the levels of CRF mRNA (Parkes et al., 1993), suggesting that central CRF per se can participate in the stimulation of neuroendocrine CRF motoneurons. Whether this effect is direct and whether the gene encoding the CRF receptor is expressed in the PVN during stress are open questions.

Vale's group (Chen et al., 1993; Perrin et al., 1993) recently cloned a cDNA coding for the CRF receptor that is widely distributed throughout the rat brain (Potter et al., 1994), but regulation of that gene in the brains of stressed animals has not been studied. It is in fact crucial to determine the effects of stressful situations on the gene encoding the CRF-R in the brain, bccausc although CRF appears to be a determinant modulator of many stress responses, the exact sites of action as well as the type of cells targeted by the peptide in the brain of challenged animals remain to be fully established. The purposes of the present study were therefore to examine the influence of a severe acute immune challenge and immobilization stress on the expression of the mRNA encoding the CRF receptor (CRF-R) in the brains of adult male rats; and to investigate whether the CRF-R was expressed in CRF-immunoreactive neurons in the PVN during normal or emergency circumstances for the organism. Immune challenge (systemic administration with the bacterial endotoxin LPS) and immobilization were used to verify the effects of a systemic and a neurogenic stress, respectively.

\section{Materials and Methods}

Animals. Adult male Sprague-Dawley ( 230-260 gm) were acclimated to standard laboratory conditions ( $14 \mathrm{hr}$ light, $10 \mathrm{hr}$ dark cycle; lights on at 0600 and off at 2000) with free access to rat chow and water. Each rat was used for experimentation only once, and all protocols were approved by the Laval University Animals Welfare Committee.

Systemic LPS administration. In the morning $(\sim 0830)$, rats received either a single intraperitoneal injection of LPS (Sigma, L-2880, lot $122 \mathrm{H} 4024,250 \mu \mathrm{g} / 100 \mathrm{gm}$ of body weight) diluted in $300 \mu \mathrm{l}$ of sterile saline $(0.9 \%)$ or the vehicle solution. This dose was selected on the basis of our previous findings that it elicits a robust activation of both IEG c-fos and NGFI-B in multiple regions of the brain and CRF gene expression in the PVN of adult male rats (Laflamme and Rivest, 1994). The purpose of that dose was also to investigate the influence of a severe immune activation on the expression of the gene encoding the CRF- $R$ in the brain. The rats were conscious and freely moving at all times throughout the experimental procedure and no mortality was observed in LPS-treated animals. One, three, six, nine, and twelve hours after the intraperitoneal treatments with the bacterial endotoxin or the vehicle solution, the animals were deeply anesthetized via an intraperitoneal injection of $0.3 \mathrm{ml}$ of a mixture of ketamine hydrochloride and xylazine, and then rapidly perfused transcardially with $0.9 \%$ saline, followed by $4 \%$ paraformaldehyde in $0.1 \mathrm{M}$ borax buffer $\left(\mathrm{pH} 9.5\right.$ at $4^{\circ} \mathrm{C}$ ). The time points were chosen on the basis of preliminary studies, which showed a strong signal for IEG mRNAs and proteins as well as CRF transcript 3 and $6 \mathrm{~h}$ after intraperitoneal LPS injection in the rat brain (Laflamme and Rivest, 1994). Brains were removed from the skull, postfixed for 4-8 d, and then placed in $10 \%$ sucrose in the solution of $4 \%$ paraformaldehyde-borax buffer overnight at $4^{\circ} \mathrm{C}$. The frozen brains were mounted on a microtome (Reichert-Jung, Cambridge Instruments Company, Deerfield, IL) and cut into $30 \mu \mathrm{m}$ coronal sections. The slices were collected in a cold cryoprotectant solution $(0.05 \mathrm{M}$ sodium phosphate buffer, $30 \%$ ethylene glycol, $20 \%$ glycerol) and stored at $20^{\circ} \mathrm{C}$.

Acute immobilization session. Rats were either killed before (time 0 : morning at $\sim 0830$ ) or placed in individual immobilizaters for $90 \mathrm{~min}$. Immobilization was performed using adjustable restraining cages (Centrap cages, Fisher Scientific 01-282-10). Cages were adjusted very tightly so that animals were unable to move once in the immobilizater, which explains our use of the term immobilization rather than restraint stress. After the stress session, rats were either killed or placed in their home cages until killed. Immediately, 1.5, 3, 6, and $12 \mathrm{hr}$ after the end of the stress session, the animals were deeply anesthetized with an intraperitoneal injection of $0.3 \mathrm{ml}$ of a mixture of ketamine hydrochloride and xylazine, and then rapidly perfused transcardially with saline, followed by $4 \%$ paraformaldehyde in $0.1 \mathrm{M}$ borax buffer $\left(\mathrm{pH} 9.5\right.$ at $\left.4^{\circ} \mathrm{C}\right)$. The brains were removed from the skull, postfixed for 4-8 d, and then placed in a solution of $10 \%$ sucrose and $4 \%$ paraformaldchydc-borax buffer overnight at $4^{\circ} \mathrm{C}$. Frozen brains were mounted on a microtome (Reichert-Jung, Cambridge Instruments Company, Deerfield, IL) and cut in $30 \mu \mathrm{m}$ coronal sections. The slices were collected and stored as described previously (see LPS treatment)

In situ hybridization histochemistry. Hybridization histochemical localization of CRF-R transcript was carried out in one in six series (every sixth section) of brain slices through the brain (from the olfactory bulb to the end of the medulla) using ${ }^{35} \mathrm{~S}$-labeled cRNA probes. Protocols for riboprobe synthesis, hybridization, and autoradiographic localization of mRNA signal were adapted from Simmons et al. (1989). All solu- 
tions were treated with diethylpyrocarbonate (Depc) and sterilized to prevent RNA degradation. Tissue sections mounted onto poly-L-lysinecoated slides were desiccated under vacuum overnight, fixed in $4 \%$ paraformaldehyde for $30 \mathrm{~min}$, and digested by proteinase $\mathrm{K}(10 \mu \mathrm{g} / \mathrm{ml}$ in $50 \mathrm{~mm}$ Tris $\mathrm{HCl}, \mathrm{pH} 8.0$, and $50 \mathrm{~mm}$ EDTA, at $37^{\circ} \mathrm{C}$ for $25 \mathrm{~min}$ ). Thereafter, the brain sections were rinsed in sterile Depc water followed by a solution of $0.1 \mathrm{M}$ triethanolamine (TEA, $\mathrm{pH} 8.0$ ), acetylated in $0.25 \%$ acetic anhydride in $0.1 \mathrm{M}$ TEA, and dehydrated through graded concentrations of alcohol $(50,70,95$, and $100 \%)$. After vacuum drying for a minimum of $2 \mathrm{hr}, 90 \mu \mathrm{l}$ of hybridization mixture $\left(10^{7} \mathrm{cpm} / \mathrm{ml}\right)$ was spotted on each slide, sealed under a coverslip, and incubated at $60^{\circ} \mathrm{C}$ overnight $(\sim 15-20 \mathrm{hr})$ in a slide warmer. Coverslips were then removed and the slides were rinsed in $4 \times \mathrm{SSC}$ at room temperature. Sections were digested by RNase A $\left(20 \mu \mathrm{g} / \mathrm{ml}, 37^{\circ} \mathrm{C}, 30 \mathrm{~min}\right)$, rinsed in descending concentrations of SSC $(2 \times, 1 \times, 0.5 \times \mathrm{SSC})$, washed in $0.1 \times \mathrm{SSC}$ for $30 \mathrm{~min}$ at $60^{\circ} \mathrm{C}(1 \times \mathrm{SSC}: 0.15 \mathrm{M} \mathrm{NaCl}, 15 \mathrm{~mm}$ trisodium citrate buffer, $\mathrm{pH} 7.0$ ), and dehydrated through graded concentrations of alcohol. After being dried for $2 \mathrm{hr}$ under the vacuum, the sections were exposed at $4^{\circ} \mathrm{C}$ to $\mathrm{x}$-ray film (Kodak) for $12-20 \mathrm{hr}$, defatted in xylene, and dipped in NTB2 nuclear emulsion (Kodak; diluted 1:1 with distilled water). Slides were exposed for 7-10 d, developed in D19 developer (Kodak) for $3.5 \mathrm{~min}$ at $14-15^{\circ} \mathrm{C}$, and fixed in rapid fixer (Kodak) for $5 \mathrm{~min}$. Thereafter, tissues were rinsed in running distilled water for $1-2 \mathrm{hr}$, counterstained with thionin $(0.25 \%)$, dehydrated through graded concentrations of alcohol, cleared in xylene, and coverslipped with DPX.

CRNA probe synthesis and preparation. The rat CRF-R probe (1.3 $\mathrm{kb}$ ) was generated from the PstI-PstI fragment of the rat prCRF PP1.3BS cDNA (Dr. W. Vale, Peptide Biology Laboratory, The Salk Institute) (Perrin et al., 1993), subcloned into pBluescript II SK (Strategene, La Jolla, CA), and linearized with BamH I and HindIII (Pharmacia) for antisense and sense probes, respectively (Perrin et al., 1993). Radioactive cRNA copies were synthesized by incubation of $250 \mathrm{ng}$ linearized plasmid in $6 \mathrm{mM} \mathrm{MgCl}_{2}, 40 \mathrm{mM}$ Tris ( $\mathrm{pH} 7.9$ ), $2 \mathrm{mM}$ spermidine, 10 $\mathrm{mM} \mathrm{NaCl}, 10 \mathrm{~mm}$ dithiothreitol, $0.2 \mathrm{~mm}$ ATP/GTP/CTP, $\alpha-{ }^{35} \mathrm{~S}-\mathrm{UTP}, 40$ U RNasin (Promega, Madison, WI), and $20 \mathrm{U}$ T7 and T3 RNA polymerase for CRF-R antisense and sense, respectively, for $60 \mathrm{~min}$ at $37^{\circ} \mathrm{C}$. Unincorporated nucleotides were removed using the ammonium-acetate method; $100 \mu \mathrm{l}$ of DNAse solution ( $1 \mu \mathrm{l}$ DNAse, $5 \mu \mathrm{l}$ of $5 \mathrm{mg} / \mathrm{ml}$ tRNA, $94 \mu \mathrm{l}$ of $10 \mathrm{~mm}$ Tris $/ 10 \mathrm{mM} \mathrm{MgCl}_{2}$ ) was added and $10 \mathrm{~min}$ later an extraction was accomplished using a phenol-chloroform solution. The cRNA was precipitated with $80 \mu \mathrm{l}$ of $5 \mathrm{M}$ ammonium acetate and $500 \mu \mathrm{l}$ of $100 \%$ ethanol for $20 \mathrm{~min}$ on dry ice. The pellet was washed with $500 \mu \mathrm{l}$ ethanol, dried, and resuspended in $100 \mu \mathrm{l}$ of $10 \mathrm{~mm}$ Tris/1 mM EDTA. A concentration of $10^{7} \mathrm{cpm}$ probe was mixed into $1 \mathrm{ml}$ of hybridization solution [500 $\mu$ l formamide, $60 \mu \mathrm{l} 5 \mathrm{M} \mathrm{NaCl}, 10 \mu \mathrm{l} 1 \mathrm{M}$ Tris, pH 8.0, $2 \mu \mathrm{l} 0.5$ м EDTA, pH 8.0, $20 \mu \mathrm{l} 50 \times$ Denhardt's solution, $200 \mu \mathrm{l} 50 \%$ dextran sulfate, $50 \mu \mathrm{l} 10 \mathrm{mg} / \mathrm{ml}$ tRNA, $10 \mu \mathrm{l} 1$ M DTT (118 $\mu$ l Depc water - volume of probe used)]. This solution was mixed and heated for $5 \mathrm{~min}$ at $65^{\circ} \mathrm{C}$ before being spotted on slides.

Quantitative analysis. Semiquantitative analysis of hybridization signals for CRF-R mRNA was carried out in nuclear emulsion-dipped slides over the confines of cells within various structures expressing the CRF-R using an Olympus Optical System (BX-50, $\beta$ Max) coupled to a Macintosh computer (PowerPC 7100/66) and IMAGE software (version 1.55 non-FPU, W. Rasband, NIH). The OD of the hybridization signal was measured under dark-field illumination at a magnification of $10 \times$ within a $10 \mathrm{~mm}$ diameter circular frame. Sections from the experimental and control animals were matched for rostrocaudal level. The size of the frame was chosen on the basis of the mean size range of neurons in these respective regions. The regions (PVN, SON, and so on) were digitized and subjected to densitometric analysis, yielding measurements of integrated OD (area of nucleus $\times$ average optical density). The OD of each specific region was then corrected for the average background signal, which was determined by sampling cells immediately outside the cell group of interest (McCabe and Pfaff, 1989).

Combination of immunocytochemistry with in situ hybridization. Immunocytuchemistry (CRF-immunoreactive neurons) was combined to the in situ hybridization histochemistry protocol (CRF-R mRNA) to determine whether CRF neurons located particularly in the PVN express the gene encoding the receptor for this stress-related peptide. Every sixth tissue slice was processed by using the avidin-biotin bridge method with peroxidase as a substrate. Briefly, slices were washed in sterile Depc-treated $0.05 \mathrm{M}$ potassium phosphate-buffered saline (KPBS) and incubated at $4^{\circ} \mathrm{C}$ with CRF antibody mixed in sterile KPBS, $0.4 \%$ Triton
X-100, 0.25\% heparin sodium salt USP (ICN Biomedicals Inc., Aurora, $\mathrm{OH}$ ), and $1 \%$ bovine serum albumin (fraction V, Sigma, St. Louis, MO). Rabbit antihuman/rat CRF serum (code PBL rc $70,8 / 9 / 83$ bleed), a generous gift of Dr. Wylie Vale (Peptide Biology Laboratory, The Salk Institute, La Jolla, CA), was used at a concentration of 1:2000. Approximately $48 \mathrm{hr}$ after incubation with the primary antibody, the brain slices were rinsed in sterile KPBS and incubated with a mixture of KPBS + heparin + biotinylated goat anti-rabbit $\operatorname{IgG}$ (1:1500 dilution; Vector Laboratories, CA) for $60 \mathrm{~min}$. Sections were then rinsed with KPBS and incubated at room temperature for $60 \mathrm{~min}$ with an avidinbiotin-peroxidase complex (Vectastain ABC elite kit, Vector Laboratories, CA). After several rinses in sterile KPRS, the brain slices were reacted in a mixture containing sterile KPBS, the chromogen 3,3'-diaminobenzidine tetrahydrochloride (DAB, 0.04\%), and $1 \%$ hydrogen peroxide $\left(\mathrm{H}_{2} \mathrm{O}_{2}\right)$.

Thereafter, tissues were rinsed in sterile KPBS, mounted onto polyL-lysine-coated slides, desiccated under vacuum overnight, fixed in $4 \%$ paraformaldehyde for $30 \mathrm{~min}$, and digested by proteinase $\mathrm{K}(10 \mu \mathrm{g} / \mathrm{ml}$ in $100 \mathrm{mM}$ Tris $\mathrm{HCl}, \mathrm{pH} 7.5$, and $50 \mathrm{~mm} \mathrm{EDTA}$, at $37^{\circ} \mathrm{C}$ for $25 \mathrm{~min}$ ). Prehybridization, hybridization, and posthybridization steps were performed as described above with the difference of dehydration (alcohol $50,70,95,100 \%$ ), which was shortened to avoid decoloration of CRF cells (brown staining). After being dried for 2 hr under the vacuum, sections were exposed at $4^{\circ} \mathrm{C}$ to x-ray film (Kodak) for $24-48 \mathrm{hr}$, defatted in xylene, and dipped in NTB2 nuclear emulsion (Kodak; diluted 1:1 with distilled water). Slides were exposed for 3 weeks, develnped in D19 developer (Kodak) for $3.5 \mathrm{~min}$ at $15^{\circ} \mathrm{C}$, and fixed in rapid fixer (Kodak) for $5 \mathrm{~min}$. Thereafter, tissues were rinsed in running distilled water for 1-2 hr, rapidly dehydrated through graded concentrations of alcohol, cleared in xylene, and coverslipped with DPX. The presence of CRF-R transcripts was evident as silver grains in perikarya, and CRF immunoreactivity within the cell cytoplasm was stained in brown.

Statistical analysis. Data shown in Figures 6 and 7 are expressed as OD for CRF-R mRNA in the hypothalamic PVN and SON of control or challenged rats. The results of the LPS experiment were analyzed by a $2 \times 5$ analysis of variance (ANOVA), and post hoc comparisons were done using an adaptation of the Dunn-Sidak test (Kirk, 1982). Factors were identified as follows: systemic treatment, which was composed of two levels (intraperitoneal vehicle or intraperitoneal LPS), and time postinjection, which combined five levels $(1,3,6,9$, and $12 \mathrm{hr}$ postinjection). Data for the stress experiment were analyzed by a $1 \times 6$ ANOVA, and post hoc comparisons were done using an adaptation of the DunnSidak test. Factor was identified as the time related to immobilization, including six levels: before (time 0), immediately after (time 1.5), 1.5 (time 3), 3 (time 4.5), 6 (time 7.5), and 12 (time 13.5) hr after the scssion.

\section{Results}

\section{Distribution of $C R F-R$ transcript throughout the rat brain}

Figures 1 and 2 illustrate representative examples of the rostrocaudal distribution of the CRF gene expression in the brains of male Sprague-Dawley rats. Hybridized tissues with sense probe did not exhibit detectable signal in any of the regions that showed positive signal with antisense probe (results not shown). As recently reported by Potter et al. (1994), strong basal levels of CRF-R transcript were observed in several regions of the brain, such as the piriform cortex, the medial nucleus of the amygdala, the basolateral nucleus of the amygdala, the caudal division of the zona incerta, the red nucleus, the laterodorsal tegmental nucleus, the pontine gray, the cerebellum, the nucleus incertus, the spinal nucleus of the trigeminal nerve (oral part), the principal sensory nucleus of the trigeminal nerve, the suprageniculate nucleus, the external cuneate nucleus, and various layers of the cerebral cortex. A low to modcratc signal was also detected in multiple sites, including the medial septal nucleus, the nucleus of the diagonal band, the bed nucleus of the stria terminalis, the supraoptic nucleus ( $\mathrm{SON}$ ), the dorsomedial nucleus of the hypothalamus, the arcuate nucleus of the hypothalamus, the parafascicular nucleus, the interpeduncular nucleus (central subnucleus), the nucleus prepositus, the medial vestib- 


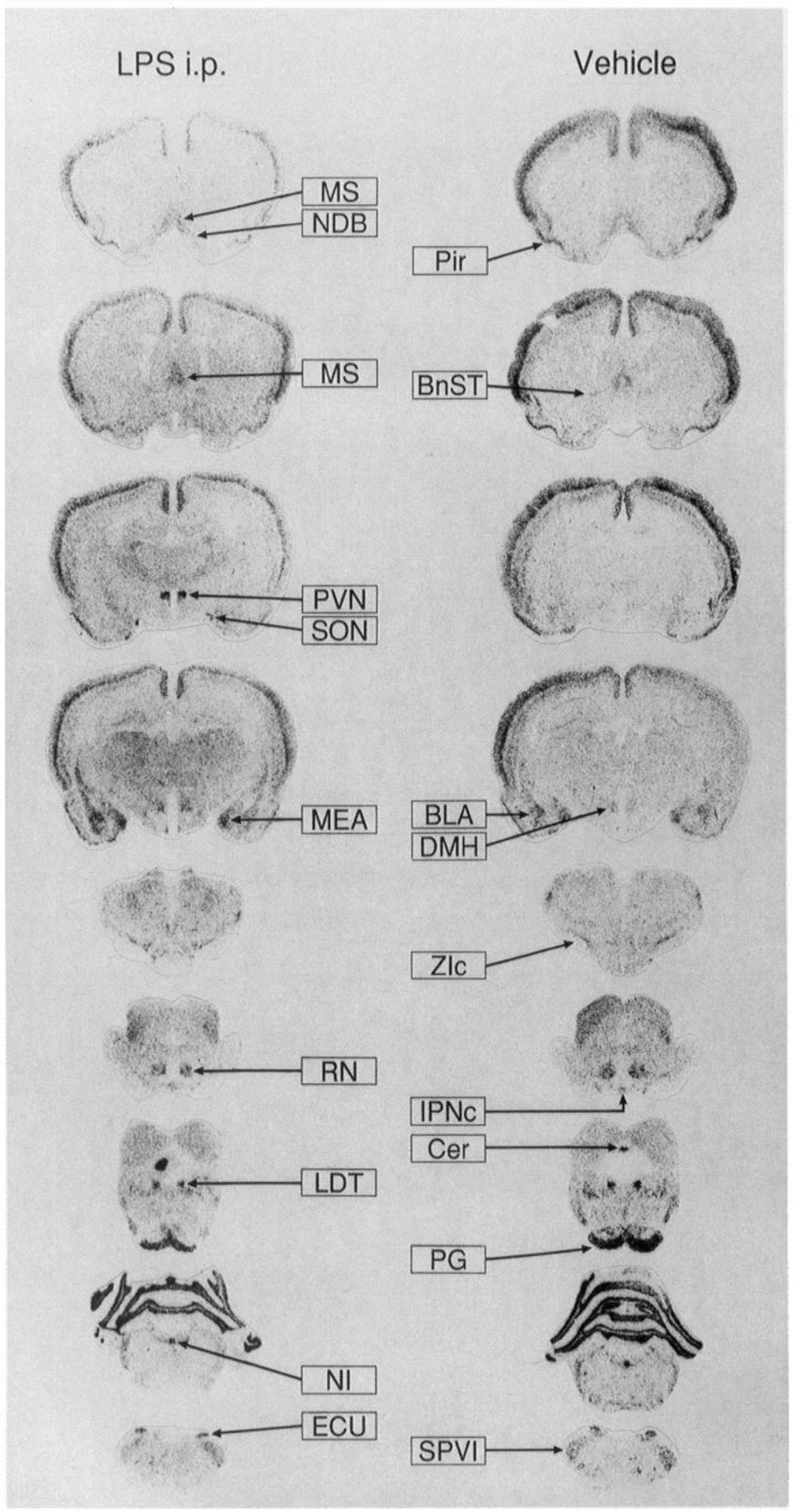

Figure 1. Representative example of the distribution of the mRNA encoding the receptor for corticotropin-releasing factor (CRF-R) in the rat brain after the intraperitoneal administration of endotoxin lipopolysaccharide (LPS) or vehicle. Animals were deeply anesthetized and rapidly perfused with $4 \%$ paraformaldehyde $6 \mathrm{hr}$ after treatment with LPS $(250 \mu \mathrm{g} / 100 \quad \mathrm{gm}$ body weight) or the vehicle solution. These rostrocaudal coronal sections $(30 \mu \mathrm{m})$ of both LPS- and vehicle-treated rat brains exhibit positive signal on $\mathrm{X}$-ray film (Kodák XAR 5) for the CRF-R transcript in the basolateral nucleus of the amygdala $(B L A)$, the bed nucleus of the stria terminalis $(B n S T)$, the cerebellum $(\mathrm{Cer})$, the dorsomedial nucleus of the hypothalamus $(D M H)$, the external cuneate nucleus $(E C U)$, the interpeduncular nucleus, central subnucleus $(I P N C)$, the laterodorsal tegmental nucleus $(L D T)$, the medial nucleus of the amygdala (MEA), the medial septal nucleus $(M S)$, the nucleus incertus $(N I)$, the nucleus of the diagonal band $(N D B)$, the piriform cortex (Pir), the pontine gray $(P G)$, the red nucleus $(R N)$, the spinal nucleus of the trigeminal nerve, interpolar part (SPVI), the caudal division of the zona incerta $(Z I c)$, and in various layers of the cerebral cortex. Note the selective induction of the CRF-R mRNA in the hypothalamic paraventricular nucleus $(P V N)$ and the supraoptic nucleus $(S O N)$ of LPS-injected rat (left column). 


\section{Stress}
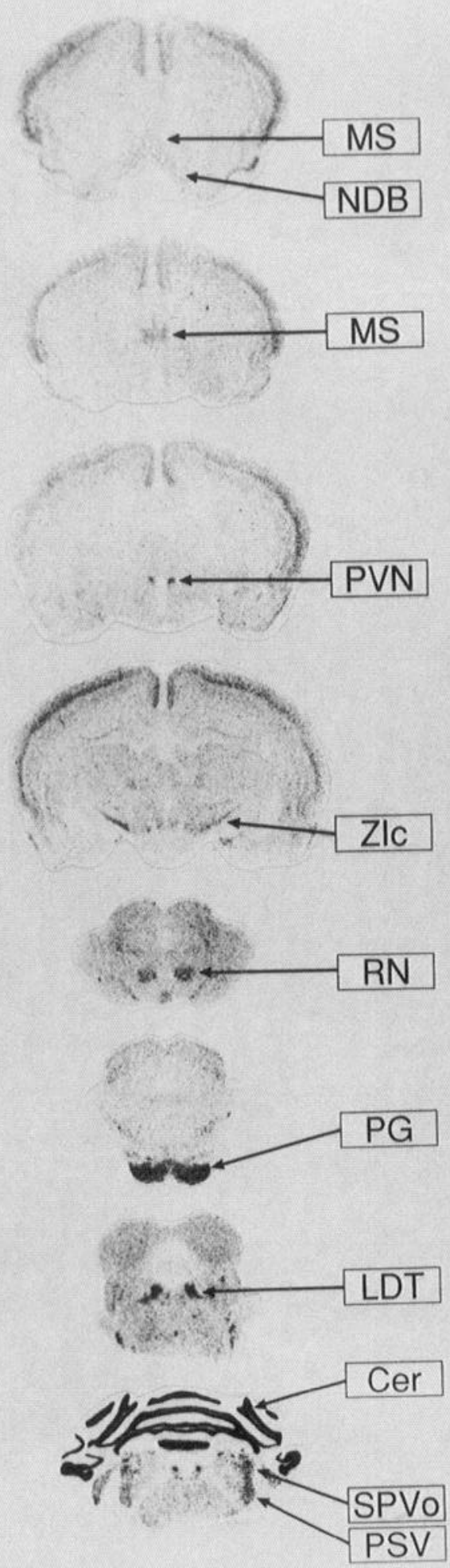

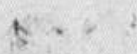

Control
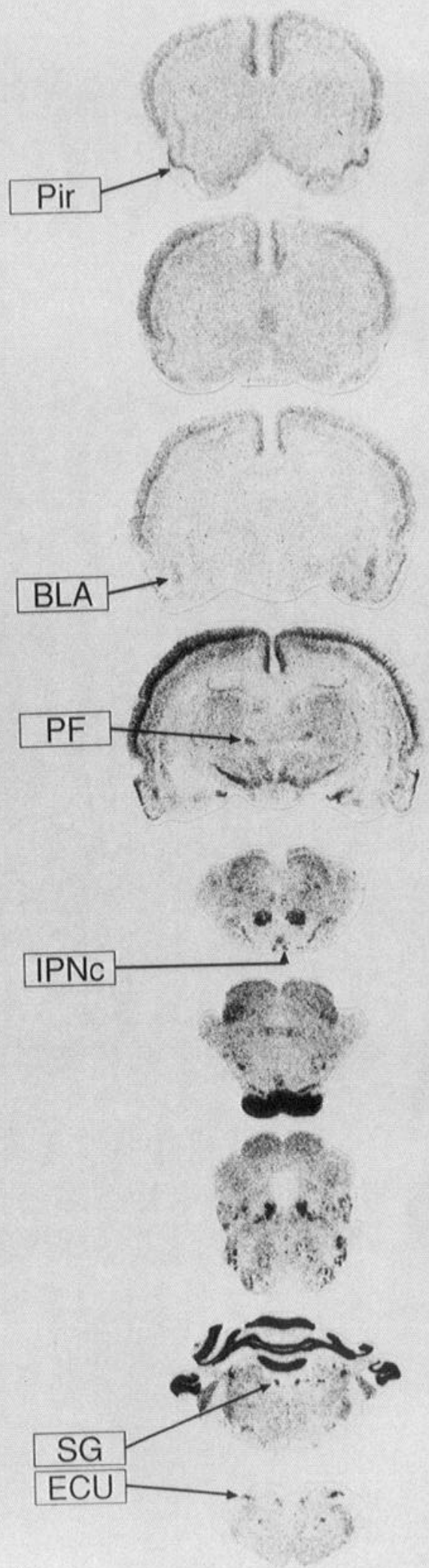

Figure 2. Representative example of the distribution of the gene encoding the corticotropin-releasing factor receptor (CRF-R) in the brain of stressed and control rats. Animals were deeply anesthetized and rapidly perfused with $4 \%$ paraformaldehyde before (Control) or 90 min after the end of the acute immobilization stress, which lasted $90 \mathrm{~min}$ (Stress, left column). These rostrocaudal coronal sections ( $30 \mu \mathrm{m})$ of both stressed and 
LPS

$1 \mathrm{~h}$

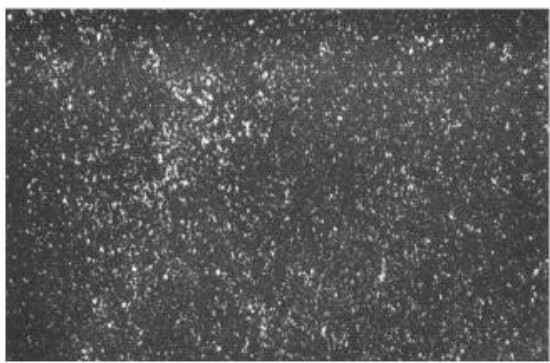

$3 \mathbf{h}$
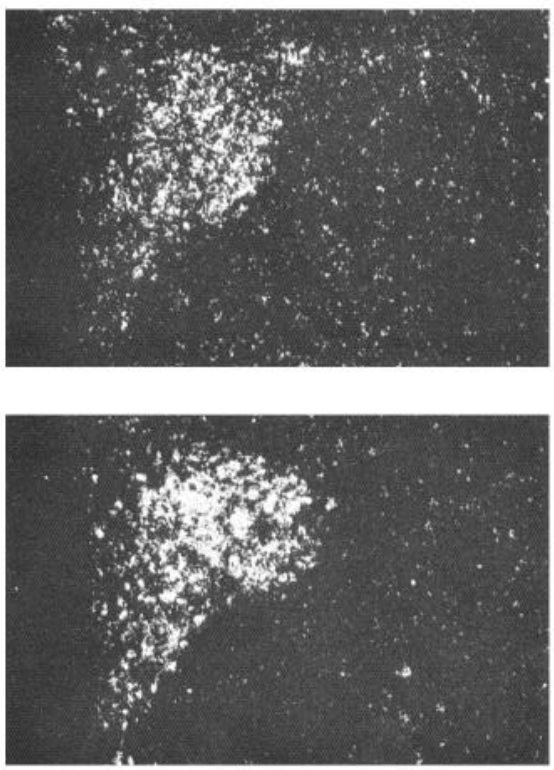

$6 \mathrm{~h}$
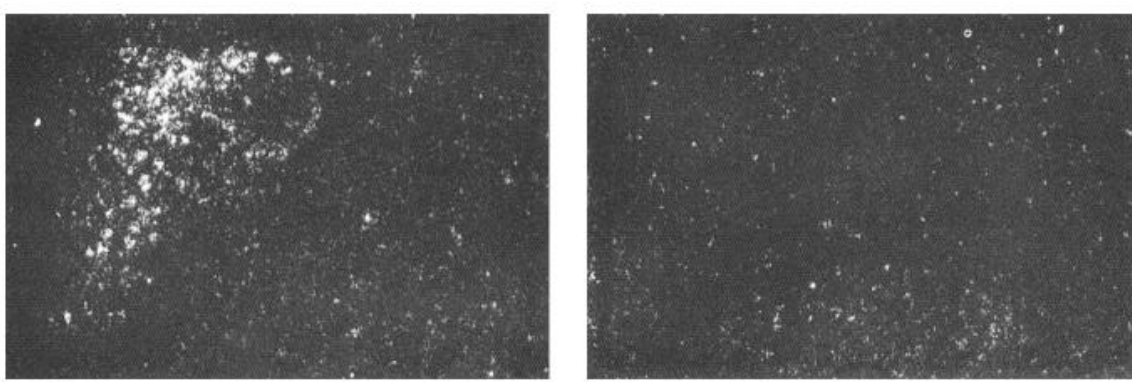

$9 \mathrm{~h}$

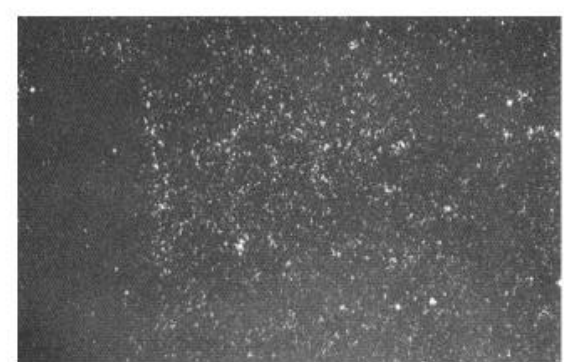

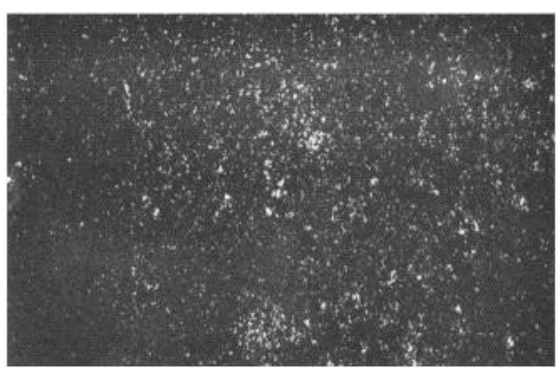
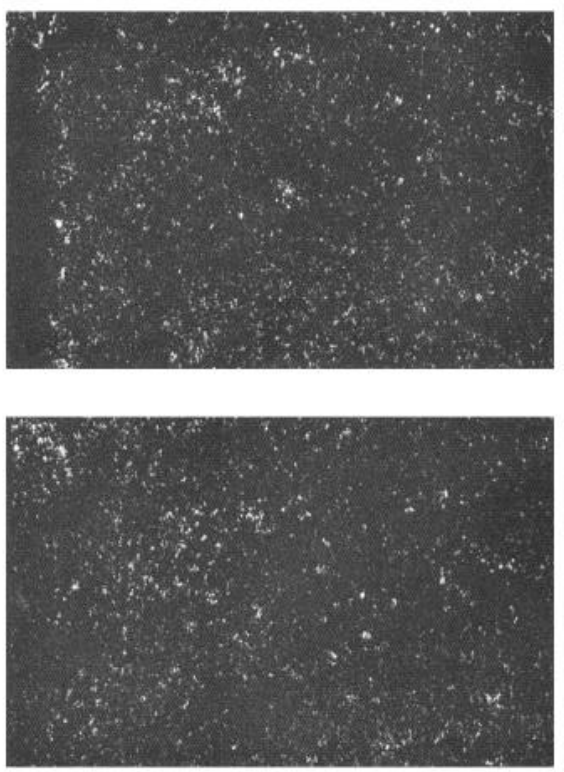

Vehicle

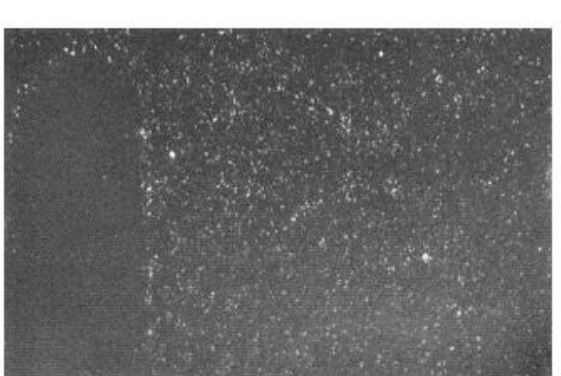

Figure 3. Influence of systemic (intraperitoneal) administration of endotoxin lipopolysaccharide (LPS) or vehicle on the expression of CRF-R mRNA in the paraventricular nucleus (PVN) of the rat hypothalamus. These photos depict dark-field photomicrographs of dipped autoradiographs of hybridized $30 \mu \mathrm{m}$ sections with CRF-R riboprobe through identical areas of the right PVN. Animals were deeply anesthetized and rapidly perfused with $4 \%$ paraformaldehyde $1,3,6,9$, and $12 \mathrm{hr}$ after the treatment with LPS $(250 \mu \mathrm{g} /$ $100 \mathrm{gm}$ body weight, left column) or the vehicle solution (right column). Note the strong signal in both parvoand magnocellular divisions of the PVN 6 hr following endotoxin injection, whereas the PVN of control rats displayed hardly detectable CRF-R transcript. Magnification 25x.

control rat brains display positive signal on x-ray film (Kodak XAR 5) for CRF-R mRNA in the basolateral nucleus of the amygdala (BLA), the bed nucleus of the stria terminalis $(B n S T)$, the cerebellum $(\mathrm{Cer})$, the dorsomedial nucleus of the hypothalamus $(D M H)$, the external cuneate nucleus $(E C U)$, the interpeduncular nucleus, central subnucleus $(I P N C)$, the laterodorsal tegmental nucleus $(L D T)$, the medial nucleus of the amygdala $(M E A)$, the medial septal nucleus $(M S)$, the nucleus incertus $(N I)$, the nucleus of the diagonal band $(N D B)$, the parafascicular nucleus $(P F)$, the piriform cortex $(P i r)$, the pontine gray $(P G)$, the principal sensory nucleus of the trigeminal nerve $(P S V)$, the red nucleus $(R N)$, the spinal nucleus of the trigeminal nerve, interpolar part ( $S P V I)$, the spinal nucleus of the trigeminal, oral part ( $S P V o$ ), the suprageniculate nucleus ( $S G$ ), the caudal division of the zona incerta $(Z I c)$, and various layers of the cerebral cortex. Note the selective induction of the mRNA encoding the CRF-R in the paraventricular nucleus of the hypothalamus $(P V N)$ of stressed rat (left column). 

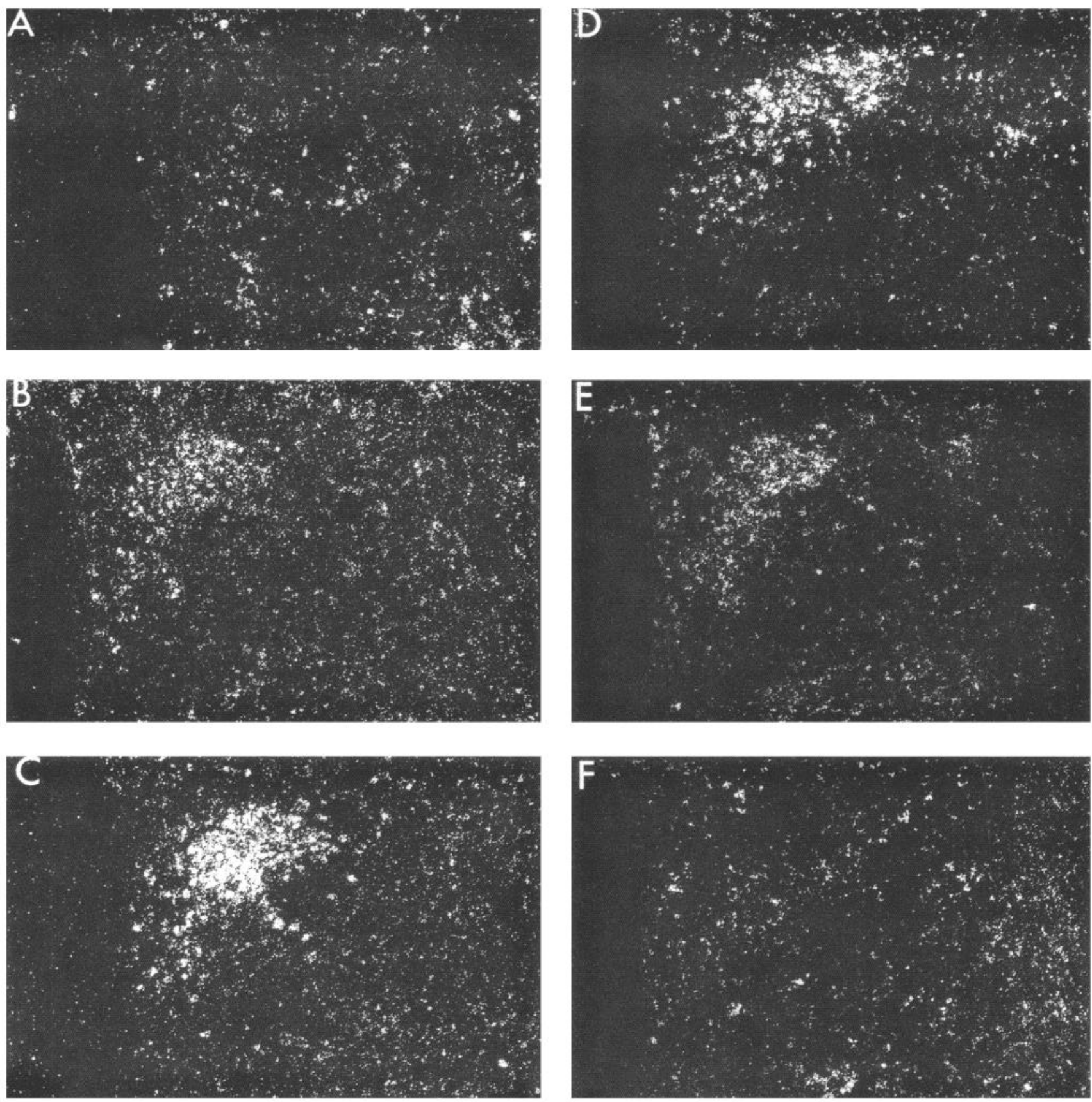

Figure 4. Acute immobilization stress induces expression of the mRNA encoding the CRF-R in the paraventricular nucleus (PVN) of the male rat hypothalamus. These photos depict dark-field photomicrographs of dipped autoradiographs of hybridized $30 \mu \mathrm{m}$ sections with CRF-R cRNA probe through identical areas of the right PVN. Animals were killed before $(A)$, immediately $(B), 1.5(C), 3(D), 6(E)$, and 12 hr $(F)$ after the 90 min stress session. Note that no visual CRF-R transcripts were observed before the stress session $(A)$, whereas the parvocellular division of the PVN exhibits a robust and selective signal $1.5(C)$ and $3 \mathrm{hr}(D)$ following the acute stress session. Magnification $25 \times$.

ular nucleus, and the spinal nucleus of the trigeminal nerve (interpolar part).

\section{Site-specific induction of CRF-R transcription in the brain of} challenged animals

Vehicle-treated (Fig. 1) and control (Fig. 2) rats displayed undetectable signals of CRF-R mRNA in the paraventricular nucleus (PVN), but CRF-R gene transcription was highly stimulated by LPS administration (Fig. 1) and immobilization stress (Fig. 2) in this hypothalamic structure. Indeed, the CRF-R
mRNA signal was positive in the dorsomedial parvocellular PVN $3 \mathrm{hr}$ after LPS injection, strong and maximum in both parvo- and magnocellular divisions of the PVN at $6 \mathrm{hr}$ postinjection, and declined 9 and $12 \mathrm{hr}$ after treatment (Fig. 3). Interestingly, CRF-R was almost undetectable in the magno-PVN of animals treated with a lower dose of LPS intraperitoneal $(25 \mu \mathrm{g}$ / $100 \mathrm{gm}$ of body weight) at $6 \mathrm{hr}$ postinjection (results not shown). In these rats, the gene encoding CRF-R was still highly expressed in the parvocellular part of the PVN (results not shown). Similarly, the signal for CRF-R mRNA was detected in the par- 
LPS
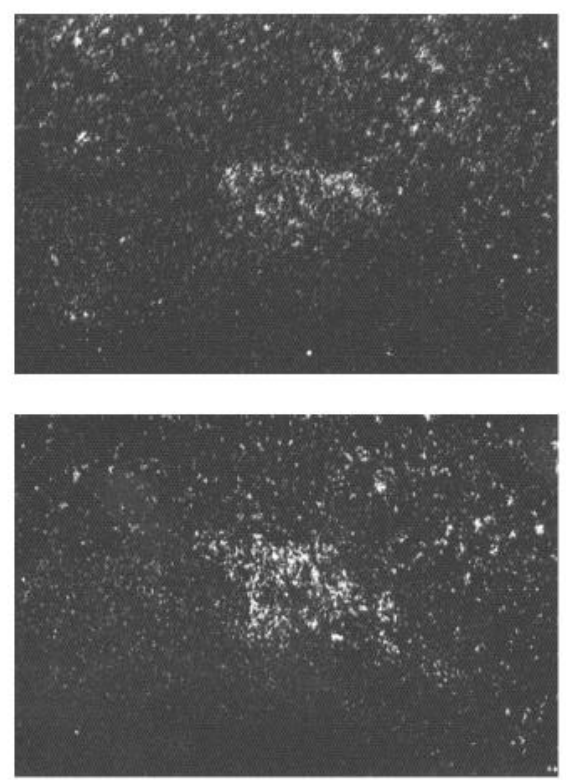

$\mathbf{3 h}$

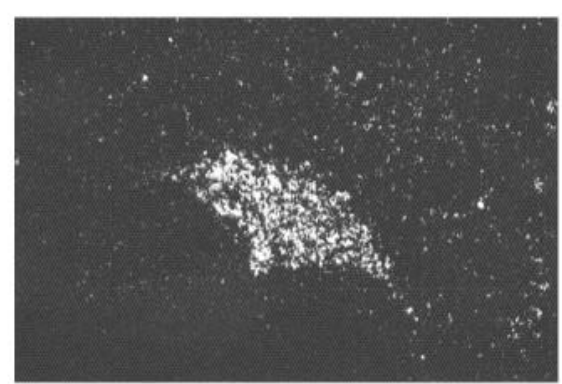

$6 \mathrm{~h}$

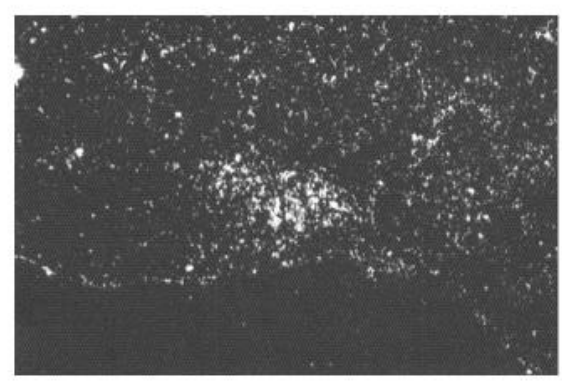

$12 \mathrm{~h}$

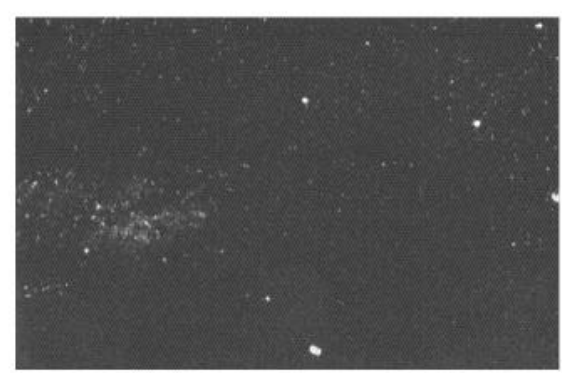

\section{Vehicle}
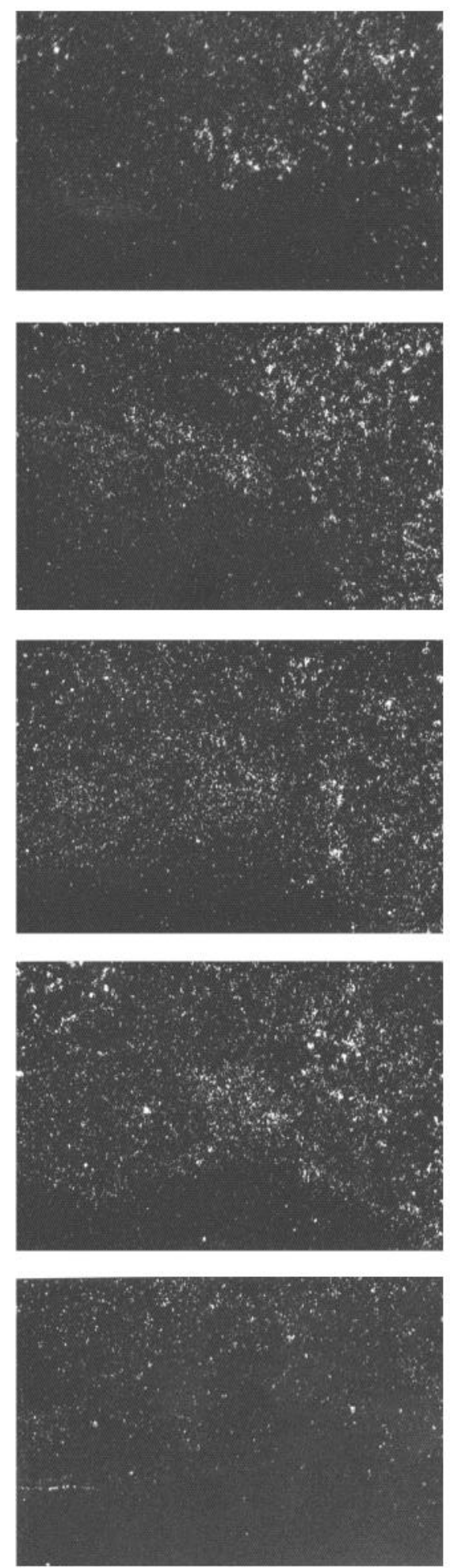

Figure 5. Effect of systemic (intraperitoneal) administration of endotoxin lipopolysaccharide (LPS) or vehicle on the expression of CRF-R mRNA in the supraoptic nucleus (SON) of the rat hypothalamus. These photos depict darkfield photomicrographs of dipped autoradiographs of hybridized $30 \mu \mathrm{m}$ sections with CRF-R riboprobe through identical areas of the right SON. Animals were deeply anesthetized and rapidly perfused with $4 \%$ paraformaldehyde $1,3,6,9$, and $12 \mathrm{hr}$ after the treatment with LPS $(250 \mu \mathrm{g} / 100 \mathrm{gm}$ body weight, left column) or the vehicle solution (right column). Note the strong signal at $6 \mathrm{hr}$ post-LPS injection (left column) compared to the small detectable expression of the CRF-R transcript in the SON of several vehicletreated rats. In fact, the basal levels of CRF-R mRNA in the SON could be classified as low to barely detectable in some animals. Magnification $25 \times$.
vo-PVN immediately after the 90 min stress session (Fig. $4 B$ ), highly expressed $90 \mathrm{~min}$ (Fig. 4C) and $3 \mathrm{hr}$ (Fig. 4D) after the immobilization session, decreased at $6 \mathrm{hr}$ (Fig. 4E), and vanished $12 \mathrm{hr}$ after the stress session (Fig. $4 F$ ). Whereas CRF-R mRNA expression was located mainly in the parvocellular division of the PVN in immobilized rats (Fig. $4 C$ ), intraperitoneal injection of a high dose of LPS induced transcription of this receptor in both parvocellular and magnocellular divisions of this hypothalamic nucleus (Fig. 3, 6 hr).

A lower but significant increase in the signal for CRF-R transcript was also observed in the SON after treatment with LPS (Fig. 5). Although a small endogenous expression of CRF-R was 

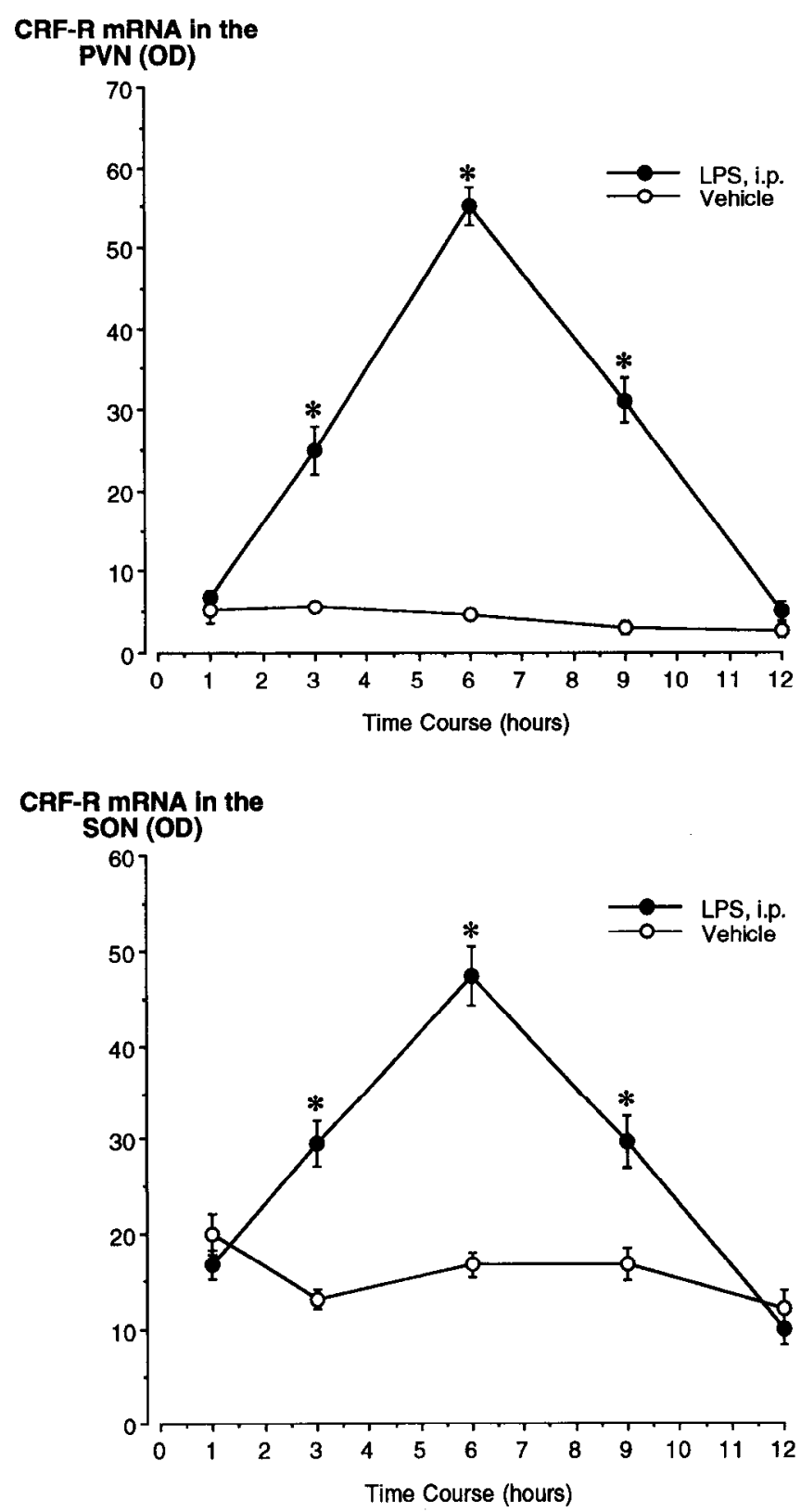

Figure 6. Influence of systemic (intraperitoneal) lipopolysaccharide (LPS; $250 \mu \mathrm{g} / 100 \mathrm{gm}$ body weight) or vehicle administration on the average optical density $(O D)$ for CRF-R mRNA signal in the paraventricular nucleus ( $P V N$, top) and the supraoptic nucleus (SON, bottom) of the rat hypothalamus. The OD was quantified in both sides of the medial PVN and the SON using an Olympus Optical System (BX-50, $\beta M a x$ ) coupled to a Macintosh computer (PowerPC 7100/66), and IMAGE software (version 1.55 non-FPU, W. Rasband, NIH). Results represent means \pm SEM of 6-8 rats. Statistical analysis was performed using a two-way analysis of variance $(2 \times 5)$ followed by a DunnSidak post hoc test (STAVIEW 4.01). ${ }^{*}, P<0.05$ from vehicle-treated rats. For more information on image analysis, see Materials and Methods.

detected in the SON of several vehiclc-treated rats, a significant $(P<0.05)$ increase in the levels of CRF-R mRNA was obtained 3,6 , and $9 \mathrm{hr}$ following the systemic treatment with the bacterial endotoxin. As for the PVN, a rapid downregulation of the gene encoding the CRF-R was also observed in this hypothalamic nucleus $12 \mathrm{hr}$ after LPS injection. However, the transcription of the gene encoding the CRF-R was not notably increased in the
SON of rats treated with a lower dose of LPS $(25 \mu \mathrm{g} / 100 \mathrm{gm}$ of body weight, results not shown). As well, the immobilization session did not increase the relative levels of CRF-R transcript in the SON, although a small positive signal was detected in several control and stressed rats.

Systemic endotoxin and immobilization stress did not appear to modulate significantly the expression of CRF-R mRNA in other regions, which provides evidence that stress induced the transcription of the gene encoding the CRF-R in very selective hypothalamic nuclei directly involved in the regulation of neuroendocrine functions.

\section{Time course of induction}

Figures 6 and 7 depict the average optical density (OD) of the hybridization signal for CRF-R transcripts after immune challenge and stress, respectively. The OD was quantified on darkfield photomicrographs of dipped autoradiographs of hybridized $30 \mu \mathrm{m}$ sections. The average OD for the CRF-R hybridized signal in both the PVN (Fig. 6, top) and the SON (Fig. 6, bottom) peaked $6 \mathrm{hr}$ after the single intraperitoneal LPS administration and returned to the level of vehicle-treated rats at $12 \mathrm{hr}$ postinjection. On the other hand, the influence of immobilization stress on the activation of CRF-R gene expression was significant in the PVN as soon as at the end of the 90 min session, but the highest average OD occurred $90 \mathrm{~min}$ after the stress period ( $3 \mathrm{hr}$ after the beginning of the immobilization). Twelve hours after the stress session, the signal for CRF-R transcripts in the PVN returned to the control level. In contrast to the severe immune challenge, the OD for CRF-R mRNA in the SON was not significantly altered by the immobilization stress (Fig. 7).

\section{Intensity of expression}

Figure 8 shows bright-ficld photomicrographs of representative examples of the number of silver grains in LPS-induced CRF-R transcription in neurons of both the PVN and the SON. Although no positive cells were observed in the PVN of vehicle-treated rats, several neurons displayed a robust level of silver grains of this hypothalamic nucleus $6 \mathrm{hr}$ after the immune challenge (Fig. 8 , top). An increase in the number of positive neurons as well as in the number of silver grains per cell was also observed in the SON of LPS-treated rats (Fig. 8, bottom). Several positive neurons containing a high level of silver grains were also detected in the parvo-PVN of immobilized animals (Fig. 9).

\section{Combination of immunocytochemistry and in situ hybridization}

To determine whether CRF-ir neurons express the gene encoding CRF-R during specific challenges, immunocytochemistry was performed before the in situ hybridization histochemistry on the same brain sections. Figure 10 shows examples of CRF-ir neurons expressing the CRF-R mRNA (filled arrowheads) in the parvocellular PVN of LPS-treated (middle) and immobilized (bottom) rats, respectively. However, not all the CRF-ir neurons of the parvo-PVN expressed the gene encoding the CRF-R protein (open arrowheads), and CRF-R-expressing perikarya not colocalized in CRF-ir neurons were also noticed in the PVN of LPS and stressed rats. In vchiclc-trcatcd (Fig. 10, top) and control (not shown) rats, none of the CRF-ir neurons (open arrowheads) exhibited positive signal for CRF-R transcript.

\section{Discussion}

The present study provides solid evidence that the gene encoding the CRF-R can be finely regulated in selective hypothalamic 
neurons, which could be directly related to the control of neuroendocrine functions such as the activity of the HPA axis. Although the CRF-R mRNA is widely distributed in the brain (Potter et al., 1994; present study), neither the immune challenge nor the immobilization stress seem to modulate the transcription of this receptor in most of these spontaneously expressing regions. In contrast, whereas the PVN displayed almost undetectable levels of CRF-R InRNA in control animals, a robust signal for this transcript was detected in this hypothalamic structure following both challenges. Interestingly, immobilization stress induced a specific expression of the gene encoding the CRF-R in the parvo-PVN, whereas systemic endotoxin produced a strong activation of CRF- $R$ transcription in both the parvo- and the magnocellular divisions of the hypothalamic PVN. Similarly, systemic LPS caused a significant increase in the levels of CRF-R mRNA in the SON, suggesting that CRF can also modulate the activity of magnoccllular neurons locatcd in both the PVN and the SON during a severe immune activation. Animals treated with a lower dose of I.PS $(25 \mu \mathrm{g} / 100 \mathrm{gm}$ of body weight) still displayed strong expression of CRF-R in the parvo-PVN but not in the magnocellular division of this hypothalamic nucleus and the SON (results not shown). In the parvocellular division, CRF perikarya can express the gene encoding the CRF$\mathrm{R}$, but whether these neurons project to the infundibular system is not known. It nevertheless seems likely that CRF plays a direct role in controlling the activity of neuroendocrine CRF motoneurons during immune challenge as well as during other types of stressful conditions for the organism.

We recently reported that intracerebroventricular administration of CRF to conscious rats can activate the expression of CRF mRNA in the parvocellular neurons of the PVN (Parkes et al., 1993), the principal seat of the neurosecretory neurons responsible for delivering CRF to the hypophyseal portal vasculature (Sawchenko and Swanson, 1990; Swanson, 1991) and driving $\Lambda$ CTH secretion (Rivier and Plotsky, 1986). This observation, together with the fact that CRF cell bodies of the parvo-PVN can express the CRF-R, indicates that CRF may be a potential modulator of its own biosynthesis selectively in the PVN of stressed rats. Moreover, central administration of CRF induces a rapid expression of various immediate early genes (c-fos and NGFI-B) in the CRF-ir neurons of the parvo-PVN (Parkes et al., 1993), a phenomenon also observed with systemic endotoxin injection and immobilization stress (Imaki et al., 1992a; Laflamme and Rivest, 1991). The temporal changes in both c-fos and NGFI-B gene expression are consistent with the hypothesis that the transcription factors encoded by these genes may be acting as early intracellular signals for direct or indirect activation of target genes such as CRF or CRF-R. In fact, intraperitoneal LPS treatment can stimulate both c-fos and NGFI-B genes in the parvocellular PVN as early as $1 \mathrm{hr}$ after the administration (Laflamme and Rivest, 1994). The SON and the magnocellular PVN also exhibit a strong signal for these two transcripts $3 \mathrm{hr}$ after endotoxin injection (Laflamme and Rivest, 1994). The signal for c-fos and NGFI-B mRNA in these brain nuclei was maximum $3 \mathrm{hr}$ postinjection, declined at $6 \mathrm{hr}$, and vanished between 9 and $12 \mathrm{hr}$ after LPS treatment. The induction of CRF-R was maximum at $6 \mathrm{hr}$ postinjection, and relative levels of CRF mRNA in the parvocellular PVN significantly increased 6 and $9 \mathrm{hr}$ after LPS treatment (Laflamme and Rivest, 1994). Whether AP-1 or NBRE can directly regulate the gene encoding the CRF-R has not been yet reported, but a relationship between IEGs, CRF-R,

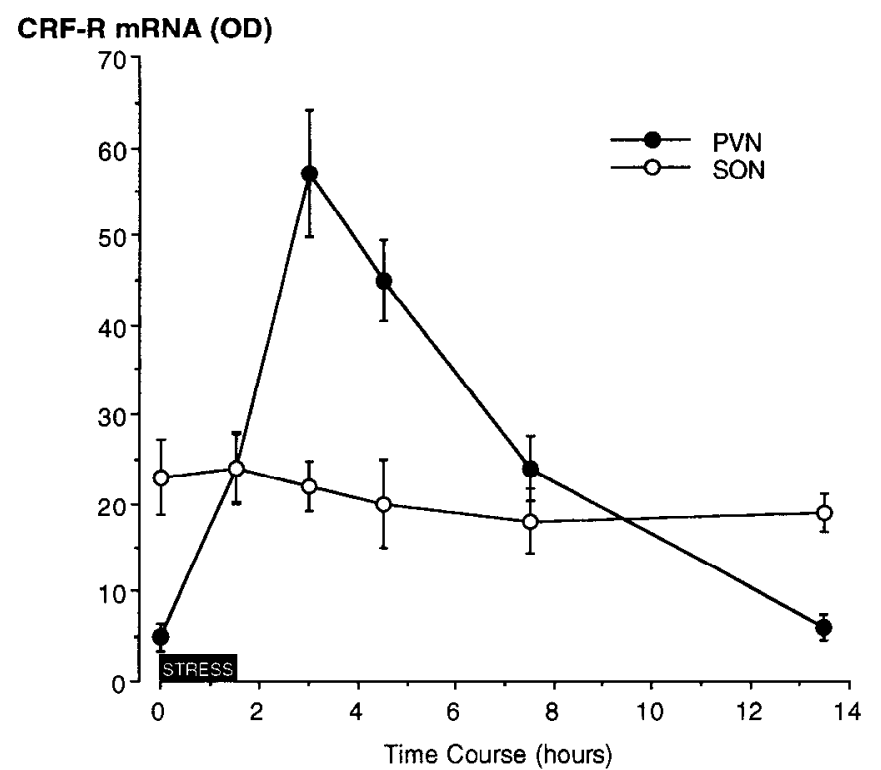

CRF-R MRNA (OD)

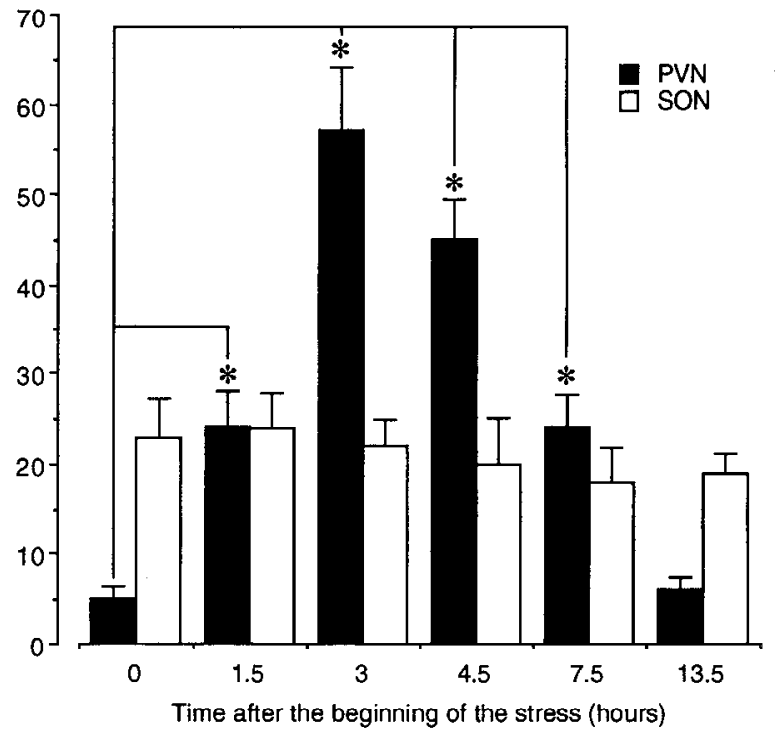

Figure 7. Effect of an acute $90 \mathrm{~min}$ session of immobilization stress on the average optical density $(O D)$ for CRF-R mRNA signal in the paraventricular nucleus $(P V N)$ and the supraoptic nucleus (SON) of the rat hypothalamus. The OD was quantified in both sides of the medial PVN and the SON using an Olympus Optical System (BX-50, $\beta$ Max) coupled to a Macintosh computer (PowerPC 7100/66), and IMAGE software (version 1.55 non-FPU, W. Rasband, NIH). Results represent means \pm SEM, and statistical analysis was performed using a one-way analysis of variance $(1 \times 5)$ followed by a Dunn-Sidak post hoc test (STAVIEW 4.01). Bottom, The areas under the curve with the statistical analyses. ${ }^{*}, P<0.05$ from control rats (time 0 , bottom). For more information on image analysis, see Materials and Methods.

and CRF biosynthesis during immune activation and other types of stressful circumstances remains possible in the parvo-PVN.

The theory of autoregulation by endogenous neuroendocrine factors has been widely studied regarding negative suppression of protein release and biosynthesis (Dallman and Jones, 1973; Piva et al., 1979; Dallman et al., 1992). However, few neuroendocrine systems, apart from the positive effects of estradiol on 


\section{LPS}

\section{PVN}

\section{Vehicle}
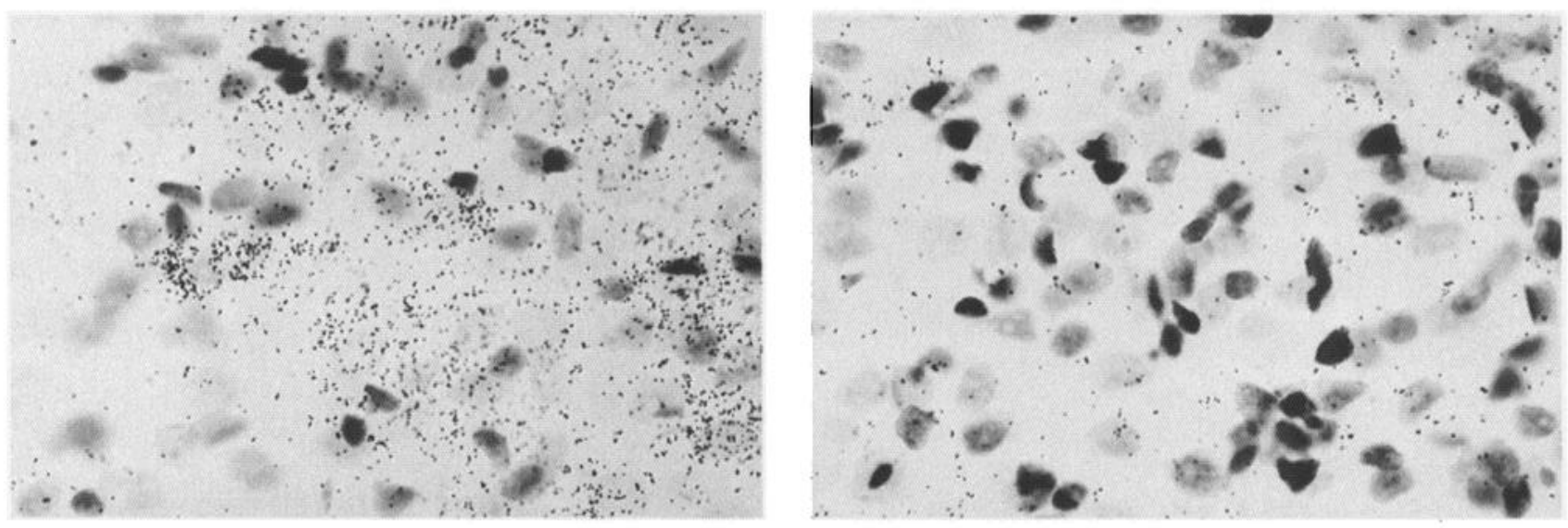

\section{SON}
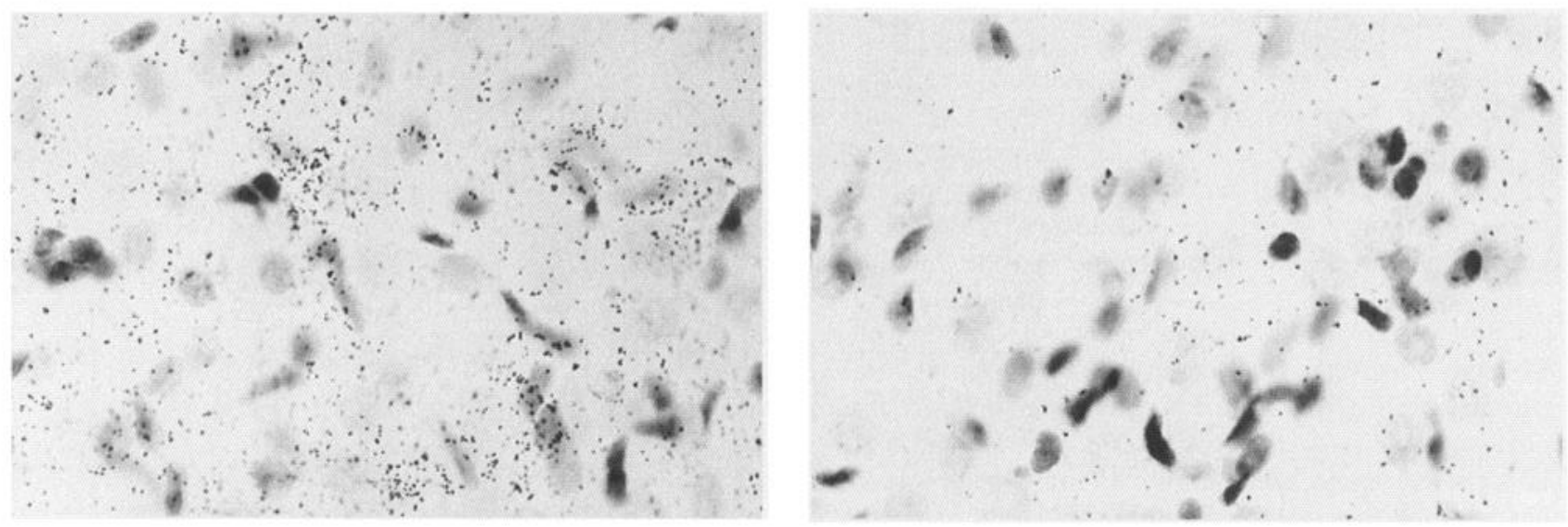

Figure 8. High-power bright-field photomicrographs of dipped autoradiographs of hybridized $30 \mu \mathrm{m}$ sections with CRF-R riboprobe through similar areas of the paraventricular nucleus $(P V N)$ and the supraoptic nucleus $(S O N)$. Animals were deeply anesthetized and rapidly perfused with $4 \%$ paraformaldehyde $6 \mathrm{hr}$ after the intraperitoneal administration of lipopolysaccharide (LPS; $250 \mu \mathrm{g} / 100 \mathrm{gm}$ body weight, left panels) or the vehicle solution (right panels). Note the number of silver grains delineating several neurons expressing the gene encoding the CRF-R in both the PVN and the SON of LPS-treated animals. Magnification 250×.

the activity of luteinizing hormone-releasing hormone (LHRH) neurons during the preovulatory LH surge, have exhibited evidence for positive feedback in either a direct or indirect manner. Negative autoregulatory mechanisms were demonstrated for oxytocin, somatostatin, and LHRH (Lumpkin et al., 1983, 1985; Richardson and Twente, 1986; Valenca et al., 1987). This decapeptide, which controls the secretion and biosynthesis of LH from the adenohypophysis, has been suggested as a candidate for short-term negative autoregulation (Sarkar, 1987; Valenca et al., 1987). In contrast, CRF per se could be involved in the stimulation of transduction pathways within PVN CRF cells to trigger the transcription of the peptide in challenged rats.

The existence of ultrashort-loop positive feedback control of CRF secretion during stress states was implied by Ono and coworkers (Ono et al., 1985). Detailed histochemical mapping of CRF neuronal fiber projections throughout the mammalian brain have shown that these fibers do indeed terminate and connect with parvocellular CRF perikarya in PVN (Silverman et al., 1989). In combining the retrograde transport of wheat-germ-con- jugated gold particles and immunocytochemistry for CRF, Beaulieu and Drolet (1994) recently described the origin of CRF innervation to the PVN. CRF-ir neurons located in the perifornical hypothalamic nucleus, the dorsolateral hypothalamic area, bed nucleus of the lamina terminalis (dorsolateral and dorsomedial), medial preoptic region, and laterodorsal tegmental nucleus/Barrington's nucles project to this hypothalamic nucleus. Besides these CRFergic projecting sites, the PVN itself could represent the origin of CRF fibers that terminate on neuroendocrine CRF perikarya. Immunohistochemical studies indicate that the PVN contains about 2000 CRF cells, which are found in all eight major parts of the nucleus; as mentioned, however, a large proportion is concentrated in the dorsomedial parvocellular part (Sawchenko et al., 1984, 1993; Swanson et al., 1986, 1983; Sawchenko and Swanson, 1990). Furthermore, CRF is expressed in a small group of neurons that project to the brainstem and the spinal cord, as well as in a subset of oxytocin cells (Sawchenko et al., 1984). In the dorsomedial parvocellular PVN, a large percentage of CRF motoneurons initially follow a laterally directed 


\section{Control}
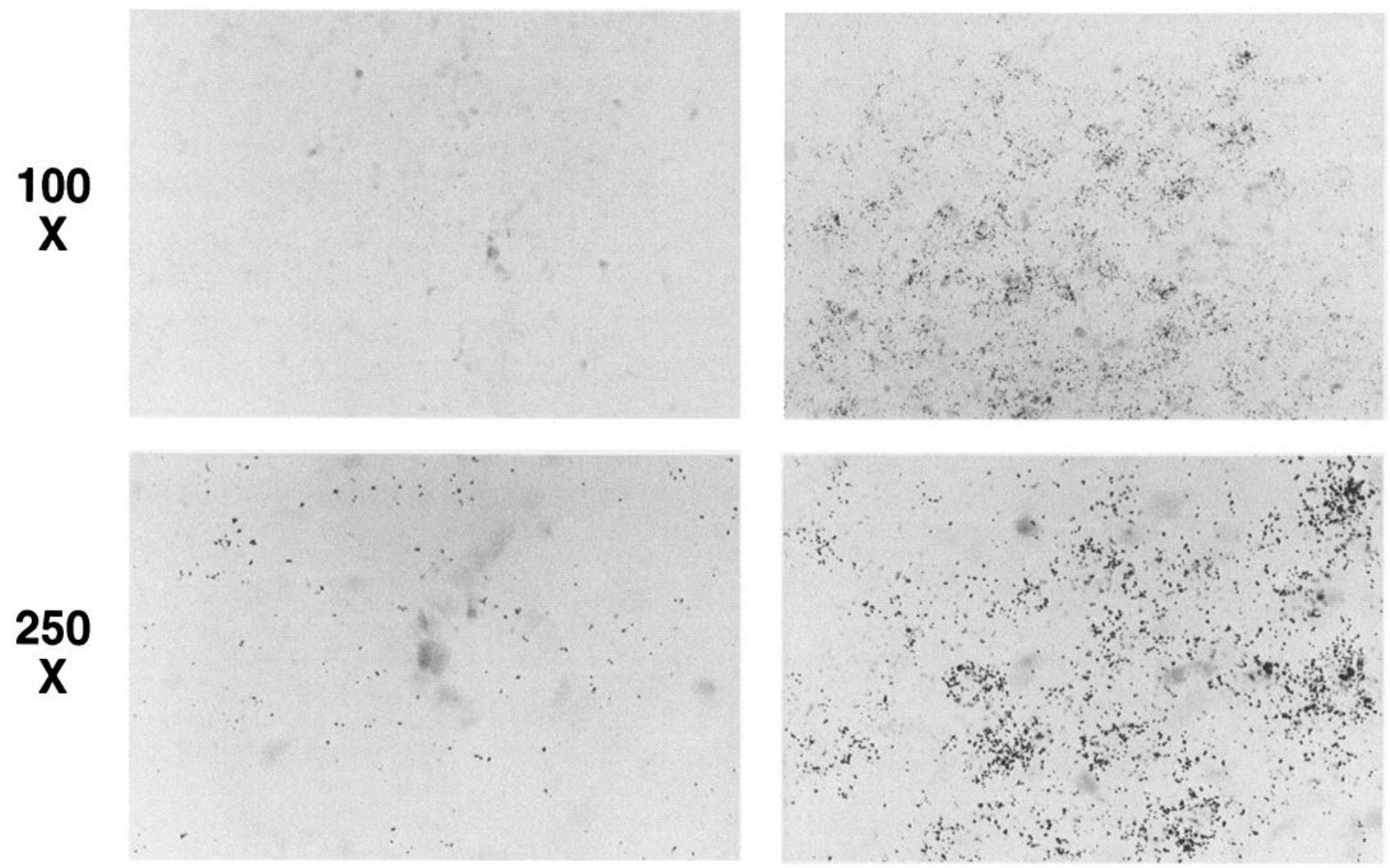

Figure 9. High-power bright-field photomicrographs of dipped autoradiographs of hybridized $30 \mu \mathrm{m}$ sections with CRF-R riboprobe through similar areas of the hypothalamic paraventricular nucleus $(P V N)$ in control and stressed rats. Rats were killed before $(C o n t r o l)$ or 90 min after the immobilization stress session (Stress), which lasted $90 \mathrm{~min}$. Note the number of silver grains delineating several perikarya expressing the mRNA encoding the receptor for CRF in the parvo-PVN of stressed rats. Magnification $100 \times$ (upper panels), $250 \times$ (lower panels).

course through and around the fornix before arching medially to end in the median eminence (Makara et al., 1981; Swanson et al., 1983). However, an elegant tract-tracing study indicated that the axons of at least some CRF neurons in the dorsomedial PVN give rise to terminal boutons around the lateral margin of the PVN, and that these cells typically display 1-3 dendrites, which branch only once or twice, and bear a sparse complement of spines (Swanson et al., 1987). CRF-CRF synapses could therefore, in theory, represent either local connections within the PVN itself or CRF neuronal projections originating from other hypothalamic or extrahypothalamic areas.

The involvement of CNS CRF in regulating the activity of neuroendocrine CRF motoneurons during immune challenges and other types of neurogenic stresses could subserve as a potential physiological relevance of the present results. Indeed, whereas CRF-immunoreactive and -expressing neurons can be detected in several structures of the CNS, only the CRF neurons located in the PVN seem to express the CRF-R gene after stressful conditions. The selectivity in the induction of the CRF-R mRNA in the CRF neurons of the PVN might indicate that (1) neuroendocrine $\mathrm{CRF}$ is the only $\mathrm{CRF}$ that can be regulated by its own receptor during stress; (2) induction of the CRF-R in the parvo-PVN is a determinant mechanism involved in the restoration of the peptide depletion after the stress period; and (3) the basal expression of the gene encoding the CRF-R in most of the brain structures is not regulated in a stress-dependent manner. It is noteworthy that CRF is among the most widely distributed neuropeptides in the CNS, but little is known about the role of CRF located outside the PVN. Even in this hypothalamic nucleus, the exact function of CRF neurons that do not send their axons to the infundibular system still remains poorly described. The fact that stimulation of CRF-R gene transcription during immobilization and immune challenge is limited to the PVN and the SON (immune stress) might suggest that CRF selectively targets these regions during stress and modulates a confined group of neurons in the brains of challenged animals. We also observed by means of CRF intronic probe technology that both immobilization and systemic LPS administration generated production of CRF heteronuclear RNA only in the PVN and not in any other sites of the brain (S. Rivest, N. Laflamme, and B. Bonaz, unpublished observations).

Interestingly, immobilization stress induced a very selective expression of CRF-R in the parvocellular division of the PVN, whereas severe acute immune challenge caused a robust transcription of this receptor in both the parvocellular and magnocellular divisions of the PVN as well as in the SON. CRF therefore appears to selectively target parvocellular neurons during immobilization stress, although parvo-PVN, magno-PVN, and 

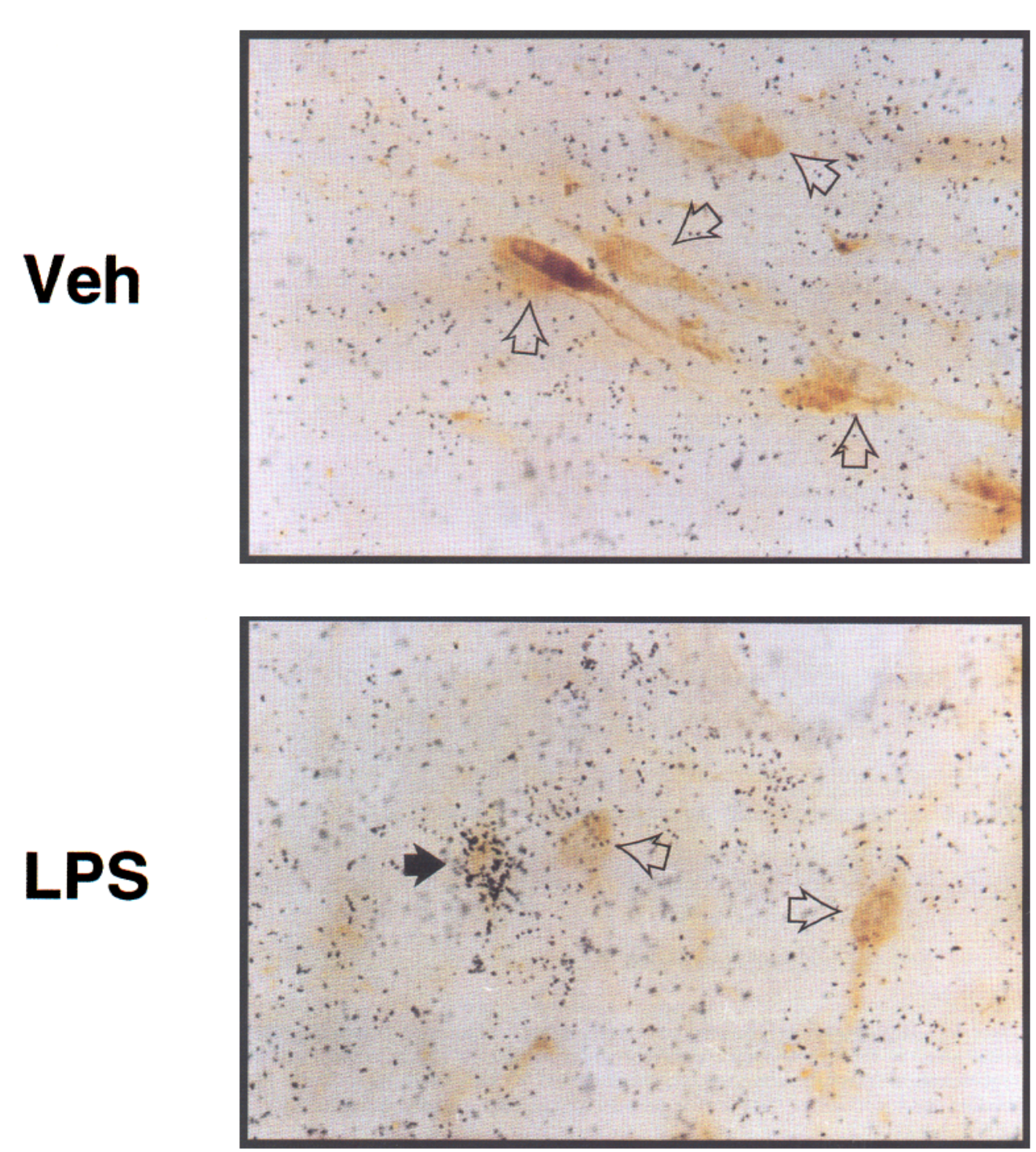

Figure 10. Expression of CRF-R mRNA in CRF perikarya located in the hypothalamic paraventricular nucleus (PVN) of LPS-treated and stressed rats. Animals were killed $6 \mathrm{hr}$ after an intraperitoneal administration of vehicle (Veh) or endotoxin (LPS; $250 \mu \mathrm{g} / 100$ gm body weight), and $90 \mathrm{~min}$ after a 90 min immobilization stress session. Immunocytochemistry (CRF protein, brown neurons) was performed on the same brain sections $(30 \mu \mathrm{m})$ before in situ hybridization histochemistry (CRF-R mRNA, silver grains). For more details on the combination of both immunocytochemistry and in situ hybridization techniques, see Materials and Methods. Filled arrowheads, CRF neurons expressing the mRNA encoding the CRF-R (middle, bottom); open Stress

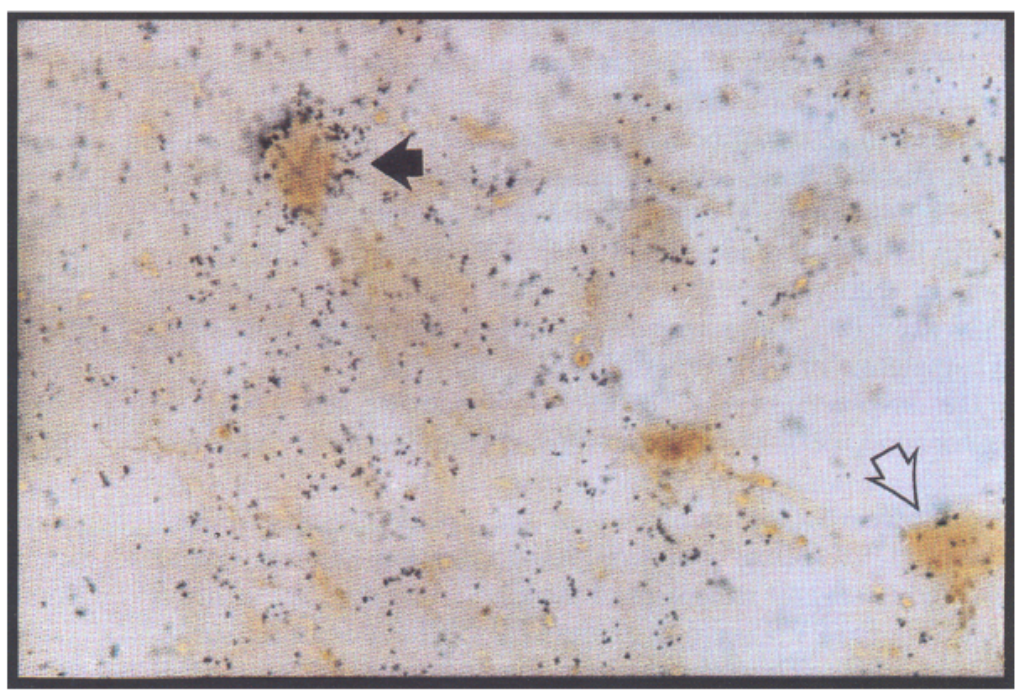
arrowheads, CRF perikarya alone. 
SON can receive specific CRFergic stimulation during systemic LPS treatment. This effect seems dependent on the intensity of immune challenge, because at lower doses $(25 \mu \mathrm{g} / 100 \mathrm{gm}$ of body weight) systemic LPS activated the transcription of CRF-R selectively in the parvo-PVN. It is possible that the action of $\mathrm{CRF}$ during neurogenic stress and a middle immune activation is limited primarily to the parvo-PVN and its influence tightly connected to the regulation of neuroendocrine CRF motoneurons. In addition to this action, CRF could be able to modulate the activity of vasopressinergic (AVP) or oxytocinergic cells located in the magnocellular division of the PVN and in the SON during a severe immune challenge. The fact that systemic LPS treatment can cause a strong induction of various immediate early genes in the PVN (parvo- and magnocellular divisions) and the SON (Laflamme and Rivest, 1994) suggests that immune challenge can stimulate not only the parvo-PVN, but also the activity of neurons located in the magno-PVN and the SON. Although the large proportion of magnocellular neurons send their axons to the posterior pituitary, it is possible that these neurons, in particular AVP neurons, contribute to the control of ACTH from the adenohypophysis. AVP plays a supportive role for CRF to stimulate the release of ACTH (Rivier and Plotsky, 1986), and immune challenge is known to activate the release of $\Lambda \mathrm{VP}$ into the hypophyseal portal circulation (Harbuz et al., 1992) and increase the levels of AVP heteronuclear RNA in the magnocellular PVN (Rivest and Laflamme, unpublished observations). Although the parvocellular division of the PVN contributes to synthesizing and releasing AVP into the infundibular system, most AVP released in portal plasma is probably derived from magnocellular neurosecretory neurons and thus participates in the control of the IIPA axis during various stressors (Buma and Nieuwenhurs, 1987; Antoni et al., 1990; Sawchenko et al., 1993).

The development of models of immune activation is actively sought because these models would produce a better understanding of the mechanisms through which infectious diseases activate the HPA axis. Endotoxins are widely used to mimic some of the events that occur during sepsis (Kushner, 1982; Dinarello, 1984; Ertel et al., 1992). Although not a true model of infection, this model represents an accepted means of increasing the release of endogenous cytokines from the peripheral immune system (Staruch and Wood, 1985; Cybulsky et al., 1987; Shalaby et al., 1989; Bristow et al., 1991). Increased production of cytokines, proteins released by activated macrophages and lymphocytes upon presentation of an antigen (Dinarello, 1989; Rabin et al., 1990), represent an essential feature of the early events of immune activation, called the acute-phase response. $\Lambda$ pri mary function of these proteins is directed toward expansion of the immunologic mass and activity by stimulating the production of growth factors. However, cytokines (such as interleukin-1) also reach the general circulation and thus can act on distant endocrine organs. The demonstration that these proteins can stimulate the neuropeptide CRF (Berkenbosch et al., 1987; Sapolsky et al., 1987; Tsagarakis et al., 1989; Barbanel et al., 1990; Suda et al., 1990; Navarra et al., 1991; Rivest et al., 1992) and the finding that subsequent activation of adrenal steroid release can in turn convey feedback signals to immune cells (Solomon, 1969) have paved the way for a better understanding of the bilateral communication pathways linking the immune and the HPA axis. Although long considered virtually independent of each other, the immune and neuroendocrine axes have thus special relevance for restoring physiological balance when chal- lenged by antigens. In this concept, the PVN and the SON, which contain many of the peptides that modulate neuroendocrine functions, seem to play a determinant role during the acute phase of an immune challenge. As mentioned, systemic administration of bacterial endotoxin induces profound activation of PVN and SON neurons (Laflamme and Rivest, 1994). The present study also presents evidence that the CRF-R could be a potential modulator in both the PVN and the SON during severe immune challenge because transcription of the gene encoding this protein is turned on selectively in these hypothalamic nuclei.

In conclusion, the gene encoding the CRF-R is widely distributed in the rat brain, but immune challenge and immobilization stress activated the transcription of that gene in very selective structures of the hypothalamus. Indeed, immobilization stress and low duses of LPS (25 $\mu \mathrm{g} / 100 \mathrm{gm}$ of body weight) induced a specific expression of CRF-R mRNA in the parvoPVN, whereas high doses of endotoxin injected intraperitoneally $(250 \mu \mathrm{g} / 100 \mathrm{gm}$ of body weight) produced a strong activation of CRF-R transcription in both the parvo- and the magnocellular divisions of this hypothalamic structure. This treatment also caused a significant increase in the levels of CRF-R mRNA in the SON, suggesting that CRF can modulate the activity of magnocellular neurons located in both the PVN and the SON of severely immune-challenged animals. In the parvocellular division of the PVN, CRF-ir neurons exhibit positive signal for the CRF-R transcript. Taken together, these results provide evidence that the gene encoding the CRF-R is finely regulated in selective regions of the brain and may play a crucial role in the control of neuroendocrine CRF motoneurons present in the dorsomedial parvo-PVN during immune challenge and other types of neurogenic stresses. Induction of CRF-R in the magnoccllular PVN and the SON could also be a determinant step involved in the cascade of events modulating the activity of other neurons, such as vasopressinergic and oxytocinergic neurons, during a severe immune activation.

\section{References}

Antoni FA, Fink G, Sheward WJ (1990) Corticotrophin-releasing peptides in rat hypophysial portal blood after paraventricular lesions: a marked reduction in the concentration of corticotrophin-releasing factor-41, but no change in vasopressin. J Endocrinol 125:175-183.

Barbanel G, Ixart G, Szafarczyk A, Malaval F, Assenmacher I (1990) Intrahypothalamic infusion of interleukin- $1 \beta$ increases the release of corticotropin-releasing hormone (CRH 41) and adrenocorticotropic hormone $(\mathrm{ACTH})$ in free-moving rats bearing a push-pull cannula in the median eminence. Brain Res 516:31-56.

Beaulieu J, Drolet G (1994) Origin of the corticotropin-releasing factor immunoreactive innervation of the paraventricular nucleus of the hypothalamus. Soc Neurosci Abstr 20:645.

Berkenbosch F, Oers JV, Rey AD, Tilders F, Besedovsky H (1987) Corticotropin-releasing factor producing neurons in the rat activated by interleukin-1. Science 238:524-526.

Brady LS, Lynn AB, Herkenham M, Gottesfeld Z (1994) Systemic interleukin- 1 induces early and late patterns of c-fos mRNA expression in brain. J Neurosci 14:4951-4964.

Bristow AF, Mosley K, Poole S (1991) Interleukin-1 $\beta$ production in vivo and in vitro in rats and mice measured using specific immunoradiometric assays. $\mathbf{J}$ Mol Endocrinol 7:1-7.

Bruhn TO, Plotsky PM, Vale WW (1984) Effect of paraventricular lesions on corticotropin-releasing factor (CRF)-like immunoreactivity in the stalk-median eminence: studies on the adrenocorticotropin response to ether stress and exogenous CRF. Endocrinology 114:5762.

Buma P, Nieuwenhurs R (1987) Ultrastructural demonstration of oxytocin and vasopressin release sites in the neural lobe and median eminence of the rat by tannic acid and immunogold methods. Neurosci Lett 74:151-157. 
Chen R, Lewis KA, Perrin MH, Vale WW (1993) Expression cloning of a human corticotropin-releasing factor receptor. Proc Natl Acad Sci USA 90:8967-8971.

Cybulsky MI, Movat HZ, Dinarello CA (1987) Role of interleukin-1 and tumor necrosis factor- $\alpha$ in acute inflammation. Ann Inst Pasteur Immunol 138:505-516.

Dallman M, Jones MT (1973) Corticosteroid feedback control of ACTH secretion: effects of stress-induced corticosterone secretion in subsequent stress response in the rat. Endocrinology 92:1367-1375.

Dallman M, Akana S, Scribner K, Bradbury M, Walker CD, Strack A, Cascio C (1992) Stress, feedback and facilitation in the hypothalamic-pituitary-adrenal axis. J Neuroendocrinol 4:517-526.

Dinarello CA (1984) Interleukin-1 and the pathogenesis of the acutephase response. N Engl J Med 311:1413-1422.

Dinarello CA (1989) Interleukin-1 and its biologically related cytokines. Adv Immunol 44:153-161.

Ericsson A, Kovacs KJ, Sawchenko PE (1994) A functional anatomical analysis of central pathways subserving the effects of interleukin-1 on stress-related neuroendocrine neurons. J Neurosci 14:897-913.

Ertel W, Morrison MH, Wang P, Ba ZF, Ayala A, Chaudry IH (1992) The complex pattern of cytokines in sepsis-association between prostaglandins, cachectin, and interleukins. Ann Surg 214:141-148.

Gong J, Zhang X, Jin RQ, Huang CS (1991) Activation of corticotropin-releasing factor-containing neurons in the paraventricular nucleus of the hypothalamus by interleukin- 1 in the rat. Neurosci Lett 132: $151-154$.

Harbuz MS, Rees RG, Eckland D, Jessop DS, Brewerton D, Lightman SL (1992) Paradoxical responses of hypothalamic corticotropin-releasing factor (CRF) messenger ribonucleic acid (mRNA) and CRF41 peptide and adenohypophysial proopimelanocortin mRNA during chronic inflammatory stress. Endocrinology 130:1394-1400.

Imaki T, Nahan JL, Rivier C, Sawchenko PE, Vale WW (1991) Differential regulation of corticotropin-releasing factor mRNA in rat brain regions by glucocorticoids and stress. I Neurosci 11:583-599.

Imaki T, Shibasaki T, Hotta M, Demura D (1992a) Early induction of $\mathrm{c}$-fos precedes increased expression of corticotropin-releasing factor messenger ribonucleic acid in the paraventricular nucleus after immobilization stress. Endocrinology 131:240-246.

Imaki T, Vale W, Sawchenko PE (1992b) Regulation of corticotropinreleasing factor mRNA in neuroendocrine and autonomic neurons by osmotic stimulation and volume loading. Neuroendocrinology 56: 633-640.

Kirk RE (1982) Experimental design: procedure for behavioral science, 2d ed, pp 110-111. Belmont, CA: Brooks/Cole.

Kushner I (1982) The phenomenon of the acute phase response. Ann NY Acad Sci 389:39-48.

Laflamme N, Rivest S (1994) Systemic endotoxin activates the genetic expression of c-fos, NGFI-B, and ncuropeptides in sclective regions of the rat brain. Proceedings of the 76th Annual Meeting of the Endocrine Society $76: 514$

Lumpkin M, Samson W, McCann S (1983) Hypothalamic and pituitary sites of action of oxytocin to alter prolactin secretion in the rat. Endocrinology 112:1711-1717.

Lumpkin M, Samson W, McCann S (1985) Effect of intracerebroventricular growth hormone releasing factor on growth hormone release: further evidence for ultrashort-loop feedback. Endocrinology 116 : 2070-2073.

Makara GB, Stark M, Karteski M, Palkovitz M, Rappay G (1981) Effects of paraventricular lesions on stimulated $A C T H$ release and $\mathrm{CRF}$ in Stalk-median eminence of the rat. Am J Physiol 240:E441-E446.

Makara GB, Stark E, Kapocs G, Antoni FA (1986) Long-term effects of hypothalamic paraventricular lesion on CRF content and stimulated ACTH secretion. Am J Physiol 250:E319-E324.

Makino S, Gold PW, Schulkin J (1994) Corticosterone effects on corticotropin-releasing hormone mRNA in the central nucleus of the amygdala and the parvocellular region of paraventricular nucleus of the hypothalamus. Brain Res 640:105-112.

McCabe JT, Pfaff DW (1989) In situ hybridization: a methodological guide. Methods Neurosci 1:98-117.

Navarra P, Tsagarakis S, Faria MS, Rees LH, Besser GM, Grossman $\mathrm{AB}$ (1991) Interleukin-1 and -6 stimulate the release of corticotropin-releasing hormone- 41 from rat hypothalamus in vitro via the eicosanoid cyclooxygenase pathway. Endocrinology 128:37-44.

Ono N, Bedran-DeCastro J, McCann S (1985) Ultrashort-loop positive feedback of corticotropin (ACTH)-releasing factor to enhance ACTH release during stress. Proc Natl Acad Sci USA 82:3528-3531.

Parkes D, Rivest S, Lee S, Rivier C, Vale W (1993) Corticotropinreleasing factor activates c-fos, NGFI-B and CRF gene expression within the paraventricular nucleus of the rat hypothalamus. Mol Endocrinol 7:1357-1367.

Perrin MII, Donaldson CJ, Chen R, Lewis KA, Vale WW (1993) Cloning and functional expression of a rat brain corticotropin-releasing factor (CRF) receptor. Endocrinology 133:3058-3061.

Piva F, Motta M, Martini L (1979) Regulation of the hypothalamic and pituitary function: long, short and ultrashort feedback loops. In: Endocrinology 1 (Degroot L, Cahill G, Odell W, Martini L, Potts J, Nelson D, Steinberger E, Winegard A, eds), pp 21-33. New York: Grune and Stratton.

Potter F, Sutton S, Donaldson C, Chen R, Perrin M, Lewis K, Sawchenko PE, Vale WW (1994) The distribution of CRF receptor mRNA expression in the rat brain and pituitary. Proc Natl Acad Sci USA 91:8777-8781.

Rabin BS, Cunnick JE, Lysle DT (1990) Stress-induced alteration of immune function. Prog Neuroendocrinimmunol 3:116-125.

Richardson S. Twente S (1986) Inhibition of rat hypothalamic somatostatin: evidence for somatostatin ultrashort loop feedback. Endocrinology 118:2076-2082.

Rivest S, Richard D (1990) Hypothalamic paraventricular nucleus lesions do not prevent anorectic effect of exercise in male rats. Am J Physiol 259 (Regul Integrative Comp Physiol 28):R579-R584.

Rivest S, Rivier C (1991) Influence of the paraventricular nucleus of the hypothalamus in the alteration of neuroendocrine functions induced by intermittent footshock or interleukin. Endocrinology 129: 2049-2057.

Rivest S, Rivier C (1994) Stress and interleukin-1 $\beta$-induced activation of c-fos, NGFI-B and CRT gene expression in the hypothalamic PVN: comparison between Sprague-Dawley, Fisher-344 and Lewis rats. J Neuroendocrinol 6:101-117.

Rivest S, Lee S, Rivier C, Richard D (1992a) Expression of FOS and CRF mRNA in the brain of female rats subjected to single or repeated running sessions. Soc Neurosci Abstr 18:194.

Rivest S, Torres G, Rivier C (1992b) Differential effects of central and peripheral injection of interleukin- $1 \beta$ on brain $c$-fos expression and neuroendocrine functions. Brain Res 587:13-23.

Rivier CL, Plotsky PM (1986) Mediation by corticotropin-releasing factor (CRF) of adenohypophysial hormone secretion. Ann Rev Physiol 48:475-494.

Sapolsky R, Rivier C, Yamamoto G, Plotsky P, Vale W (1987) Interleukin-1 stimulates the secretion of hypothalamic corticotropin-releasing factor. Science 238:522-524.

Sarkar D (1987) In vitro secretion of LHRH in ovariectomized rats is regulated by possible autofeedback mechanisms. Neuroendocrinology 45:510-516.

Sawchenko PE, Swanson LW (1990) Organization of CRF immunoreactive cells and fibers in the rat brain: immunohistochemical studies. In: Corticotropin-releasing factor: basic and clinical studies of a neuropeptide (DeSouza E, Nemeroff C, eds), pp 29-51. Boca Raton, FL: CRC.

Sawchenko PE, Swanson LW, Vale WW (1984) Corticotropin-releasing factor: co-expression within distinct subsets of oxytocin-, vasopressin-, and neurotensin-immunoreactive neurons in the hypothalamus of the male rat. J Neurosci 4:1118-1129.

Sawchenko PE, Imaki T, Potter E, Kovács K, Vale W (1993) The functional neuroanatomy of corticotropin-releasing factor. In: Ciba Foundation symposium, Corticotropin-releasing factor (Chadwick DJ, Marsh J, Ackrill K, eds), 172:5-29. Chichester: Wiley.

Shalaby MR, Waage A, Aarden L, Espevik T (1989) Endotoxin, tumor necrosis factor- $\alpha$ and interleukin 1 induce interleukin- 6 production in vivo. Clin Immunol Immunopathol 53:488-498.

Silverman AJ, Hou-Yu A, Chen WP (1989) Corticotropin-releasing factor synapses within the paraventricular nucleus of the hypothalamus. Neuroendocrinology 49:291 299.

Simmons DM, Arriza JL, Swanson LW (1989) A complete protocol for in situ hybridization of messenger RNAs in brain and other tissues with radio-labeled single-stranded RNA probes. J Histotechnol 12: 169-181.

Solomon GF (1969) Stress and antibody response in rats. Int Arch Allergy 35:97-108.

Staruch MJ, Wood DD (1985) Reduction of serum interleukin-1-like 
activity after treatment with dexamethasone. J Leukocyte Biol 37: 193-207.

Suda T, Tozawa F, Ushiyama T, Sumitomo T, Yamada M, Demura H (1990) Interleukin-1 stimulates corticotropin-releasing factor gene expression in rat hypothalamus. Endocrinology 126:1223-1228.

Swanson LW (1991) Biochemical switching in hypothalamic circuits mediating responses to stress. Prog Brain Res 87:181-200.

Swanson LW, Simmons DM (1989) Differential steroid hormone and neural influences on peptide mRNA levels in CRH cells of the paraventricular nucleus: a hybridization histochemical study in the rat. $\mathbf{J}$ Comp Neurol 285:413-435.

Swanson LW, Sawchenko PE, Rivier J, Vale WW (1983) Organization of ovine corticotropin releasing factor (CRF)-immunoactive cells and fibers in the rat brain: an immunohistochemical study. Neuroendocrinology 36:165-186.

Swanson LW, Sawchenko PE, Lind RW (1986) Regulation of multiple peptides in CRF parvocellular neurosecretory neurons: implications for the stress response. Prog Brain Res 68:169-190.
Swanson LW, Sawchenko PE, Lind RW, Rho JH (1987) The CRH motoneuron: differential peptide regulation in neurons with possible synaptic, paracrine, and endocrine outputs. Ann NY Acad Sci 512: $12-23$.

Tsagarakis S, Gillies G, Rees LH, Besser M, Grossman A (1989) Interleukin-1 directly stimulates the release of corticotrophin-releasing factor from rat hypothalamus. Neuroendocrinology 49:98-101.

Vale W, Spiess J, Rivier C, Rivier J (1981) Characterization of a 41residue ovine hypothalamic peptide that stimulates secretion of corticotropin and $\beta$-endorphin. Science 213:1394-1397.

Valenca M, Jonhson C, Ching M, Negro-Vilar A (1987) Evidence for a negative ultrashort loop feedback mechanism operating on the luteinizing hormone releasing hormone neuronal system. Endocrinology $121: 2256-2261$.

Young WS (1986) Corticotropin-releasing factor mRNA in the hypothalamus is affected differently by drinking saline and by dehydration. FEBS Lett 208:158-162. 